\title{
A SUMMARY OF THE EARTHWORM FAUNA OF BURMA WITH DESCRIPTIONS OF FOURTEEN NEW SPECIES
}

\author{
By G. E. Gates \\ Judson College, Rangoon, Burma
}

\section{INTRODUCTION}

This paper is the first of a series which, it is hoped, will eventually present the results of an extensive as well as comprehensive survey of the terricolous oligochaete fauna of the province of Burma. There are numerous climatic, geographical, and for the time being, financial difficulties which prevent the orderly progress of such a survey. Further papers will necessarily appear, therefore, as circumstances permit, and for the immediate future at least, without reference to any methodical systematic or geographical sequence.

The writer wishes to thank for assistance given during the course of preparation of the present paper the United States National Museum, Harvard University, the United States Bureau of Fisheries, and the Marine Laboratories at Woods Hole; and Misses McNab and Carpenter for aid with illustrations

\section{GEOGRAPHICAL CONSIDERATIONS}

The Province of Burma lies between $8^{\circ}$ and $28^{\circ} 30^{\prime}$ north latitude, and between $92^{\circ} 11^{\prime}$ and $101^{\circ} 91^{\prime}$ east longitude. It includes an area of approximately 240,000 square miles. The extreme length is about 1,300 miles and the greatest width about 700 miles. The Province is said to be composed of seven natural regions: Two coastal strips, Arakan and Tenasserim; three hilly or mountainous regions, the western hills, the northern hills, and the Shan Plateau; and two central regions, the deltas and the dry zone. However, the country is commonly thought to comprise only two distinct regions which are called colloquially the "Plains" and the "Hills." (Fig. 1.)

The first-mentioned region may be designated the Central Basin region. This extends from the sea northward between the hills of the Burmese-Javan are and the Indo-Malayan mountains to the

No. 2781.-Proceedings U. S. National Museum, Vol. 75, Art. 10 
mountainous ranges reaching into Burma in a north and south direction from the Himalayas. This portion of the country consists of broad, undulating table-lands, rolling downs, and alluvial plainsincluding the deltas of the Irrawaddy and Sittang Rivers, and the valleys of the Chindwin, Mu, Sittang, and Irrawaddy Rivers. The delta of the Salween River may conveniently be included in this region. With the exception of the Pegu Yomas which separate the valleys of the Irrawaddy and Sittang Rivers, the land is less than a thousand feet above the level of the sea. Most of the cultivated land is within this region as well as a very large proportion of the population.

That portion of the country commonly called the "Hills" may be designated the Peripheral Hill region. This section of the country is largely over a thousand feet above sea level, with considerable areas above the 3,000-foot level, and walls off the central basin region from the rest of Asia. The mountains of the western limb of this peripheral region pass, with interruptions by the sea, through the Andaman and Nicobar Islands, Sumatra, Java, and New Guinea. Similarly the mountains of the eastern limb pass southward, through a small portion of Siam and the Malay Peninsula. On the western slopes of the Arakan and Tenasserim Hills are narrow coastal strips much broken up by the sea. There are numerous islands off both coasts, those west of Tenasserim constituting the Mergui Archipelago. The Peripheral Hill region is sparsely inhabited and covered with jungle of varying density except on the grassland plains of the Shan Plateau.

\section{HISTORICAL CONSIDERATIONS}

Our knowledge of the Oligochaete fauna of the Province of Burma has been based almost entirely on the study of museum specimens incidentally obtained by collectors who were primarily interested in other groups of animals. As might be expected, under these circumstances references in the literature to Burmese forms are rather scarce. The first significant contribution ${ }^{1}$ was a series of three papers by Daniele Rosa in the Annals of the Civic Museum of Genoa, Italy,

\footnotetext{
${ }^{1}$ Actually the first record of an earthworm from Burma is a description of Perionyx m'intoshi from Akyab published in 1883 . The species was founded for a single immature worm. Some years later Beddard (1892) described more completely under the same specific name mature worms obtained from India, but indicated doubt as to the identity of the Burmese and Indian forms by prefixing, in the synonymy, the original reference with an interrogation mark. ("My observations upon Perionyx m'intoshi were made upon a single, not sexually mature, example; they were therefore not quite conclusive as to the distinctness of the species.") Michaelsen omitted Burma from the habitat of this species in his list of 1908. Stephenson, on the other hand, included P. m'intoshi in his list of Burmese forms. The specific identification of immature earthworms is notoriously difficult and is not usually attempted by sys. tematists. In view of this difficulty and the distance between the Burmese and Indian habitats it hardly seems wise at the present time to attach any particular importance to Beddard's record.
} 
in which the following were either described or recorded from Burma for the first time:

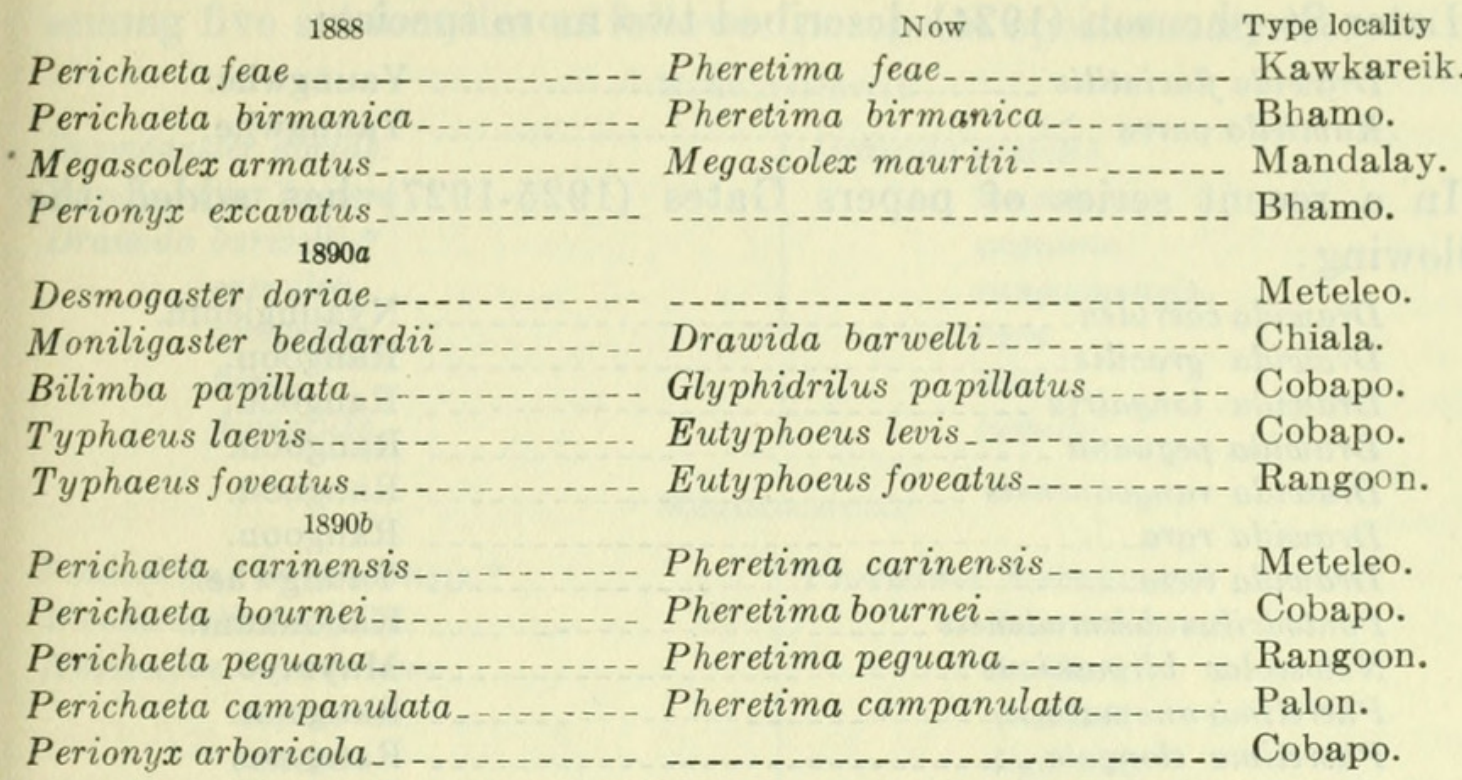

These worms had been secured by Signor Leonardo Fea in the course of four years collecting in a region extending from Moulmein to Bhamo.

Smaller collections of earthworms made by friends and officers of the Indian Museum at Calcutta have been studied by Michaelsen and by Stephenson. Three new species were described by Michaelsen in 1907:

Eupolygaster browni
Woodwardia bunkilli_......... Lashio.
Pheretima andersoni $\ldots \ldots \ldots$ Buthidaung, Akyab.

In an elaboration of the 1907 paper Michaelsen (1908) added:

Pheretima heterochaeta Manchio.

In this paper Burma is included in the habitat of Pheretima houlleti, the writer considering Rosa's $P$. campanulata to be a synonym of $P$. houlleti. Stephenson in 1923 followed Michaelsen in this respect. It has since been shown (Gates 1927a) that Rosa's species is valid.

Stephenson, in three papers in the Records of the Indian Museum, recorded three further species from the Province:

1912. Pheretima posthuma Yenangyaung, etc.

1916. Pheretima lignicola Thinganyinaung, etc.

1918. Perionyx fulvus Inle Lake.

In 1923 Stephenson listed 37 species of earthworms from Burma. The area designated by this name included, however, in addition to Burma proper, the Andaman and Nicobar Islands, as well as Rangamati, a district which is part of the Province of Bengal. Seventeen of the worms so listed had been found in only one of these three 
extra-provincial areas. $P$. houlleti and P. m'intoshi were included and $P$. campanulata, $P$. posthuma, and E. levis ${ }^{2}$ were omitted.

Later Stephenson (1924) described two more species:

Drawida fluviatilis _.............. Yaungwhe.
Ramiella parva

In a recent series of papers Gates (1925-1927) has added the following:

Drawida caerulea
Drawida gracilis
Drawida longatria
Drawida rangoonensis
Drawida rara
Drawida tecta

In an appendix to a short paper on a species of Notoscolex Gates (1927b) listed 42 worms from the Province. Thisincluded P.m'intoshi but not $P$. campanulata. The paper had been written early in 1926 , but owing to a series of mischances had not been published until after the appearance of the paper in which $P$. campanulata was restored to specific status.

The present paper contains descriptions of 14 new species listed below, and notes on two known species:

Drawida constricta
Drawida flexa
Drawida tumida
Notoscolex depressus
Notoscolex lunatus
Pheretima minuta
Pheretima ornata
Octochaetus lunatus
Eutyphoeus bifovis
Eutyphoeus constrictus
Eutyphoeus excavatus
Eutyphoeus hastatus...
Eutyphoeus planatus
Eutyphoeus similis

${ }^{2}$ This species was founded for a single specimen which was so poorly preserved that only the external characters were described. The absence of genital markings indicates that the worm was also immature. The species must therefore be considered invalid. 
At the present time that portion of the oligochaete fauna of the Province which is known comprises 56 valid species distributed among five subfamilies as follows (peregrine species starred):

\section{MONILIGASTRINAE}

Desmogaster doriae.

Eupolygaster browni.

Drawida barwelli.*

caerulea.

constricta.

flexa.

fluviatilis.

Drawida gracilis.

longatria.

peguana.

rangoonensis.

rara.

tecta.

tumida.

Megascolecinae

Pontodrilus bermudensis.*

Woodwardia burkilli.

Notoscolex birmanicus.

depressus.

lunatus.

Megascolex mauritii.*

Pheretima anomala.

andersoni.

birmanica.

bournei.

companulata.*

carinensis.

elongata.*

feae.

\begin{tabular}{|} 
Pheretima hawayana.* \\
heterochaeta.* \\
houlleti.* \\
insolita. \\
lignicola.* \\
minuta. \\
ornata. \\
peguana.* \\
planata.* \\
posthuma.* \\
Perionyx arboricola. \\
excavatus.* \\
fulvus.*
\end{tabular}

OCTOCHAETINAE

Octochaetus birmanicus.

lunatus.

Eutyphoeus bifovis.

constrictus.

excavatus.

foveatus.

hastatus.

Eutyphoeus planatus.

peguanus.

rarus.

similis.

spinulosus.

Ramiella parva.

Glossoscolecinae

Pontoscolex corethrurus.*

MicrochaETINAE

Glyphidrilus papillatus.*

\section{ZOÖGEOGRAPHICAL CONSIDERATIONS}

LOCAL DISTRIBUTION

If a line be drawn on a map of Burma from Moulmein west to Bassein, thence north to Mandalay, and then south to Moulmein, a triangular area in the southern half of the central basin region will be marked off. The relatively small and possibly least interesting portion of the Province thus delimited contains practically all of the localities where anything has been done in the way of collecting 
earthworms. Very little is known about the worms of regions lying outside of this triangle. Only one endemic form is known from the district south of Moulmein, one from that portion of the central region north of Mandalay, and one from the Akyab district on the western border of the Province, while all records of occurrence in the "Hills" are of four localities, not widely separated, in the Shan Plateau (mideastern section of the Peripheral Hill region). Practically all of the hill country to the west, north, and far south, the two coastal strips, as well as the middle and northern portions of the central basin region are yet to be investigated. Within the triangle there are many important areas which have not yet been studied, and only the district immediately around the town of Rangoon can be considered adequately explored.

Furthermore a considerable proportion of the earthworm fauna of any locality can be obtained only during the rainy season (Gates, 1926c). Most collecting has been done hitherto, except in Rangoon and the immediate vicinity, only toward the end of the rainy season or in the dry season months. It is therefore at least possible, if not probable, that numerous species are yet to be found, even in those localities where extensive collections have already been made.

In view of these circumstances it is not feasible at the present moment to attempt an extensive discussion of the distribution of the local forms. It may be of interest, however, to point out briefly, certain "tendencies" in the accumulating knowledge of the earthworms of the Province.

Most important of these tendencies is the apparent restriction of worms to one or the other of the two major regions. (The peregrine species are marked with an asterisk in the list on p. 5.) The endemic species belong to 10 genera, 6 of which (with 8 species)-

\begin{tabular}{l|l} 
Desmogaster & Notoscolex \\
Eupolygaster & Perionyx \\
Wamiella
\end{tabular}

have been collected only in the Peripheral Hill region. Two genera (with 12 species) -

Octochaetus

| Eutyphoeus

have been found only in the plains of the central basin region. Although the two remaining genera have been taken in both the "Hills" and "Plains," only three forms-

Drawida longatria

Pheretima insolita

Pheretima anomala

have been found in both regions, whereas eight species of Drawida appear to be confined to the "Plains" and two to the "Hills." Similarly four of the nine endemic Pheretima seem to be restricted 
to the "Hills" and three to the "Plains." Even some of the peregrine species appear to be similarly limited to one or the other of the two major regions of the Province. Four species-

Megascolex mauritii

Pheretima peguana

$\mid \begin{aligned} & \text { Pheretima planata } \\ & \text { Pontoscolex corethrurus }\end{aligned}$

have been collected only in the "Plains," while two other species Pheretima hawayana

| Pheretima heterochaeta

have been taken only in the Shan Plateau.

Other tendencies may be mentioned more briefly. Every new collection brings to light new species, usually belonging to two important genera, Drawida and Eutyphoeus. Even when the collections are made at places only comparatively short distances away from regions already studied, new forms are found. Thus, at places as near to each other as Rangoon and Bassein or Mandalay and Meiktila distinctly different species of Eutyphoeus occur. It hardly seems possible to move 200 miles in any direction from any locality without entering regions containing at least several new species. In contrast to this multiplicity of species only three significant genera have been added to the local fauna in the last 17 years and all three belong to families previously known to occur in the Province.

EXTRA PROVINCIAL DISTRIBUTION

Two subfamilies, the Glossoscolecinae and the Microchaetinae, and four genera-

Pontodrilus

Pontoscolex

Megascolex

Glyphidrilus

are represented in the Burmese region only by peregrine species. Two subfamilies, the Moniligastrinae and the Megascolecinae, and three genera-

Drawida

Perionyx

Pheretima

are represented in the local fauna by both endemic and peregrine species. The remaining family, the Octochaetinae, and seven genera-

Desmogaster

Eupolygaster

Woodwardia

Notoscolex

Octochaetus
Eutyphoeus
Ramiella

are represented in this Province only by endemic species. None of the indigenous forms belong to genera restricted to this Province. Burma is thus related zoogeographically to certain other regions, as follows: Desmogaster and Eupolygaster have been found in Sumatra and Borneo; Drawida occurs in South India and Ceylon, the eastern 
Himalayas, Bengal, Central India, and possibly Borneo; Woodwardia has been taken in South India and Ceylon, Australia, and Java; Notoscolex in South India and Ceylon, the eastern Himalayas, Australia, and New Zealand; Pheretima in southeastern and eastern Asia; Perionyx in India, Australia, Sumatra, and Java; Octochaetus has been found elsewhere only in New Zealand and India (all of the Indian and Burmese species belong to the distinct subgenus Octochaetoides); Ramiella and Eutyphoeus have been collected only in India.

Interesting theories have been put forward to explain these relationships. Discussion of these theories so far as Burma may be concerned is unprofitable at present and will be reserved for some future paper.

SUMMARY

1. The number of endemic species common to both the central basin region and the Peripheral Hill region is small. Less than half of the peregrine species may be said to occur in both regions.

2. The Moniligastrinae with the exception of Drawida are confined to the "Hills." One species of Drawida has been found in both "Hills" and "Plains."

3. The Octochaetinae except Ramiella are restricted to the central and southern portions of the central region. Ramiella is limited to the "Hills."

4. In the large subfamily Megascolecinae, Woodwardia, Notoscolex, and Perionyx (except two peregrine species) are confined to the peripheral region, while Pheretima is present in both sections.

5. The dominant genus in the central plains seems to be Eutyphoeus, in the "Hills" possibly Notoscolex.

6. The endemic species belong to genera which occur outside of Burma in one or more of the following areas: Sumatra, Java, and Borneo; South India and Ceylon; Australia and New Zealand; the Malay Archipelago; the eastern Himalayas, including Abor and Assam.

\section{SYSTEMATIC CONSIDERATIONS ${ }^{3}$}

DRA WIDA CONSTRICTA, new species

Description of the type-specimen, external characteristics (Cat. No. 19251, U.S.N.M.).-Length, $73 \mathrm{~mm}$. Diameter, 3-31/2 mm. Number of segments, 148. Color: Grayish, except on the clitellum where the segments are deep red.

The prostomium is prolobous.

${ }^{3}$ It should be pointed out that the collections on which this portion of the paper is based were made for the writer by various individuals, none of whom have had biological or other scientific training. In some instances the collecting was done in quite unfavorable months. This will explain the necessity for certain remarks hereafter. 
Segments vii to xiii have a secondary furrow posterior to the setae of the segment. Segments $x$ to xiii have a second furrow anterior to the setae of the segment. Most of the segments posterior to the clitellar region have two slight secondary furrows to each segment, one anterior to and one posterior to the setae of the segment.

There are pore like depressions in the intersegmental furrows from $4 / 5$ posteriorly, but apparently no functional dorsal pores.

The setae begin on ii, and are closely paired; $a b$ is equal to $c d, a a$ is less than $b c$, and $d d$ is about one-half of the circumference.

The clitellum is on $\mathrm{x}$-xiii (4).

The male pores are on the conical papillae on $10 / 11$, and are slightly external to $b$.

The female pores are in $11 / 12$ and are in line with $b$.

The spermathecal pores are in $7 / 8$ in the region of $c d$.

The most conspicuous genital marking is the conical papilla on each side of the worm in the furrow $10 / 11$. The inner edge of the papilla is internal to $b$. The papillae are bent slightly toward each other and are constricted slightly at the base by a circumferential furrow and bear at the tip the male pores. Posterior to the setae of $\mathrm{x}$ and extending to $c$ on each side is a transversely elongate depression, slightly deeper at each end than in the middle. On each side of xi, posterior to the setae, and in line with the male porophore is a slight depression. On segment

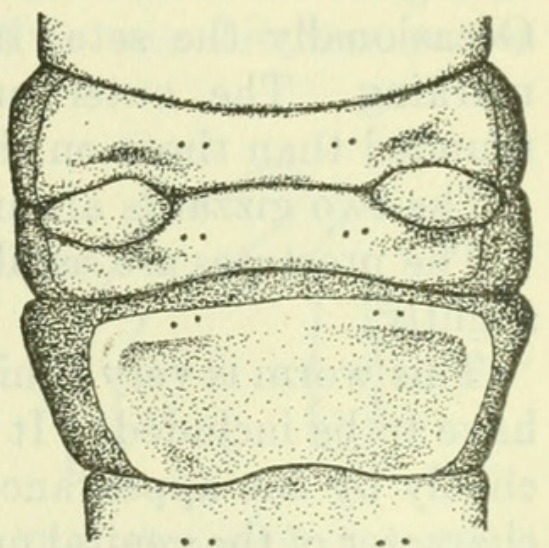

Figure 2.-Drawida constricta. EXTERNAL VIEW OF VENTRAL GENITAL REGION xii, behind the setae, and extending slightly beyond $b$ on each side is an oval, concave, glandular like area, sharply delimited by a circumferential furrow.

Internal anatomy.-Septa $5 / 6,6 / 7,7 / 8$, and $8 / 9$ are thickened.

There are two gizzards in segments xvi and xvii. The wall of the alimentary canal is slightly thickened in $\mathrm{xv}$.

The last pair of hearts is in ix.

The testis sacs are ovoid bodies in ix and $x$, half in each segment. The vas deferens is a small coiled mass on the posterior surface of $9 / 10$, under each testis sac, and passes into the middle of the prostate. The prostates are small dome-shaped bodies on the parietes. The surface is coarsely granulated.

The ovarian chamber is closed dorsally just over the alimentary canal. The ovisacs extend into xv. The spermathecal ampulla is large and ovoid on the posterior face of $7 / 8$. The duct is fine and is coiled into several loops.

Distribution.-Mandalay, Prome, Thayetmyo. 
Remarks.-The clitellum is usually on $\mathrm{x}$-xiii, but occasionally extends onto ix and xiv. The male porophores appear to be characteristic but the other genital markings vary considerably, as in other species of this genus. Many of the Mandalay worms have a small whitish depression on each side on segments $\mathrm{x}$ and $\mathrm{xi}$ in line with the male porophore. Occasionally the two depressions of $\mathrm{x}$ are confluent at the center to form a single elongate depression. In some of the specimens glandular areas are present in the region of the depressions or the depression may be lacking and the glandular areas slightly elevated. Oval, smooth-surfaced, concave areas similar to the one on xii in the type-specimen may occur on $\mathrm{ix}$, xi, xii, or xiii. In specimens collected at Prome and Thayetmyo the unpaired markings on ix and xii are slightly different in appearance, extending through all of region $c c$ on the posterior portion of the segment which is enlarged to 4-6 times the width of the segment anterior to the setae. Occasionally the setae are included in the anterior border of the marking. The outer ends of these markings are more bluntly rounded than those on the Mandalay specimens.

The two gizzards are in segment $\mathrm{xv}$ and $\mathrm{xvi}$ or $\mathrm{xvi}$ and $\mathrm{xvii}$.

The prostates are sessile and project into the body cavity only very slightly.

This worm is very similar to $D$. rara, with which it may eventually have to be included. It is to be distinguished from the latter species chiefly by the appearance of the male porophores, the position and character of the genital markings, and the smaller number of gizzards.

\section{DRAWIDA FLEXA, new species}

Description of the type-specimen, external characteristics (Cat. No 19252, U.S.N.M.).-Length, $104 \mathrm{~mm}$. Diameter, 31/2-5 mm. Number of segments, 238. Color: Grayish white, except on the clitellum where the segments are reddish.

The prostomium is prolobous.

Segment vii has a deep secondary furrow posterior to the setae. Segments viii, ix, etc., posteriorly, have two secondary furrows per segment, one anterior to and one posterior to the setae of the segment.

Dorsal pores are lacking.

The setae begin on segment ii and are closely paired; $a b$ is equal to $c d, a a$ is greater than $b c, d d$ is slightly greater than one-half of the circumference.

The clitellum is on $\mathrm{x}$-xiii.

The male pores are on $10 / 11$, in $b c$, slightly nearer $b$ than $c$, and are surrounded by slight, whitish, glandular elevations on $\mathrm{x}$ and $\mathrm{xi}$.

The female apertures are in $11 / 12$, just external to $b$.

The spermathecal pores are in $7 / 8$, just internal to $c$. 
The genital markings are small, nearly round, whitish elevations with a grayish spot at the center. They are located on segments vii, $x, x i$, and xii. Those on vii lie in contact with $7 / 8$ in line with $c d$, on each side. The papillae on $\mathrm{x}$ are in $b c$ about equidistant from $b$ and $c$, and are in line with the eight setae of the segment. The markings on xii are in $b c$, in line with the papillae of $\mathrm{x}$ but are on the anterior border of the segment in contact with 11/12. There is a single median papilla in $a a$ on xi, in contact anteriorly with $10 / 11$.

Internal anatomy. - Septa 5/6,6/7, 7/8, and $8 / 9$ are thickened.

The four gizzards are in segments $\mathrm{xix}, \mathrm{xx}$, xxi, and xxii.

The last pair of hearts is in segment ix.

The large testis sacs are in ix and $x$, constricted by $9 / 10$. The vas deferens is coiled into a small mass on the posterior face of $10 / 11$, under the testis sac of each side. The prostate is bent into a horseshoe shape, with the opening toward the nerve cord and the posterior limb passing into the parietes. The vas deferens passes into the end of the anterior limb.

Segment $x i$ is reduced to a small closed chamber. The ovisacs extend into $\mathrm{xv}$. The spermathecal ampulla is large and ovoid. The duct is coiled into a small

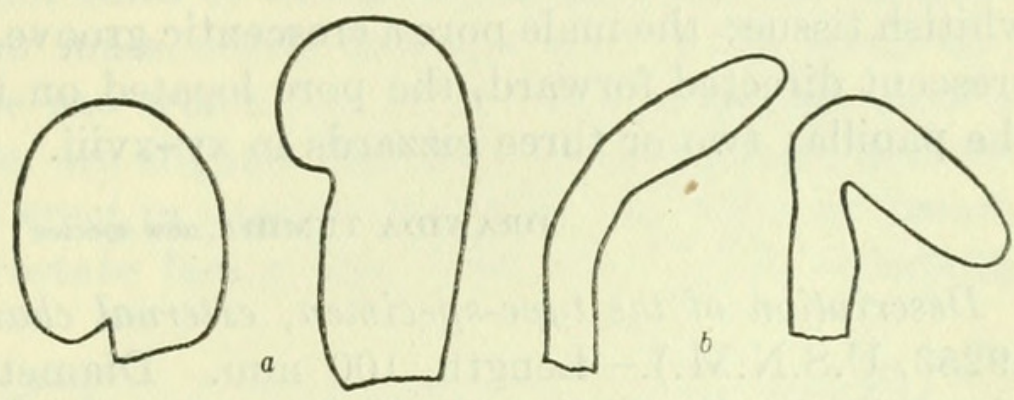

Figure 3.-Drawida flexa. a. Prostates $X$ about 14 . b. atria $X$ ABOUT 14

mass on the posterior face of $7 / 8$ immediately under the ampulla, and is looped as it passes from the ampulla along the septum to the parietes. The atrium in vii is finger shaped and stands erect in the segment.

Distribution.-Kyundo, Kawkareik (October).

Remarks. - The length varies from 80-110 mm., and the diameter from $31 / 2-4 \mathrm{~mm}$. at the posterior end to $4 \frac{1}{2}-5 \frac{1}{2} \mathrm{~mm}$. at the anterior end.

The male pores of most of the specimens are at the tops of slight conical elevations on 10/11. The spermathecal pores are in line with $c$ or $d$, just internal to $c$ or just external to $d$.

The four gizzards are in xviii-xxi, xix-xxii, or $\mathrm{xx}-\mathrm{xxiii}$.

The prostates are coiled or bent into various positions.

The small round genital papillae occur on segments vii-xii. They are paired in $b c$ on the anterior or posterior borders of the segments. Unpaired median papillae occur in $a a$ on the anterior, middle, or posterior thirds of segments vii, ix, $\mathrm{x}$, and xi.

The atria are often bent at various angles. 
Drawida longatria Gates, Ann. Mag. Nat. Hist., ser. 9, vol. 16, p. 50, 1925.

Distribution.--Mandalay, Thazi.

Remarks.-In a collection from Mandalay are two forms which appear superficially to be different from each other as well as from $D$. longatria. The spermathecal atrium, the vas deferens, and the prostates are, however, characteristic of $D$. longatria.

In specimens of the first form definitely marked genital papillae are lacking; the male porophores are bluntly rounded projections in $10 / 11$; the testis sacs lie in both $\mathrm{x}$ and $\mathrm{xi}$; the gizzards are two or three in $\mathrm{xv}-\mathrm{xvii}$; the atria are short, 20-30 $\mathrm{mm}$. long, with large loosely coiled loops and with the free end very slightly enlarged.

In specimens of the second form genital papillae are also lacking; the male porophores are slightly elevated, flat-surfaced, oval areas extending across $10 / 11$, about three-fourths of the papilla on segment $\mathrm{x}$, the portion of the papilla on $\mathrm{x}$ surrounded by a narrow strip of whitish tissue; the male pore a crescentic groove, with the horns of the crescent directed forward, the pore located on the posterior part of the papilla; two or three gizzards in $\mathrm{xv}-\mathrm{xviii}$.

DRA WIDA TUMIDA, new species

Description of the type-specimen, external characteristics (Cat. No. 19253, U.S.N.M.).-Length, $100 \mathrm{~mm}$. Diameter, $4 \mathrm{~mm}$. Number of segments 197. Color: Grayish, except on the clitellum where the segments are deep red.

The prostomium is prolobous.

Segments vii-xx, inclusive, have two secondary furrows per segment, one anterior to and the other posterior to the setae of the segment. Slighter tertiary furrows are present on $\mathrm{x}$ and $\mathrm{xi}$.

Functional dorsal pores are lacking.

The setae begin on segment two and are closely paired; $a b$ is equal to $c d, a a$ is less than $b c$, and $d d$ is greater than one-half of the circumference.

The clitellum is on $\mathrm{x}$-xiii (4).

The male pores are in $10 / 11$, in $b c$, nearer $b$ than $c$, on the tops of roughly conical papillae.

The female pores are in $11 / 12$ in line with $b$.

The spermathecal apertures are in $7 / 8$ in line with $c$.

The body wall in $b c$ near $b$ is thrown into a longitudinal ridge on each side, extending from $9 / 10$ to the setae of xi. Two papillae are seated on each ridge. The body wall between the two ridges is grayish instead of red. The whitish male porophores are on the posterior end of the ridges and are roughly conical with the pointed tip directed slightly inward and posteriorly. The anterior papillae 
are larger, whitish, ovoid bodies with the long axis parallel to the long axis of the body. The papillae extend from just posterior to the setae of $\mathrm{x}$ to $9 / 10$, which is displaced slightly forward just in front of the papillae. The male porophores are incised by concentric circumferential furrows. The inner surface of the anterior papillae is smooth, flat, oval in outline, and the outer surface is incised by three or four longitudinal furrows.

On the posterior border of vii, in contact with $7 / 8$, and extending from just external to $d$ to halfway between $b$ and $c$ on each side, is an oval smooth surfaced area marked off by a circumferential furrow.

Internal anatomy. - Septa 5/6,6/7, 7/8, and $8 / 9$ are thickened.

The gizzards are four in xvii-xx. The wall of the alimentary canal is thickened and whitish in xxi.

The last pair of hearts is in ix.

The testis sacs are asymmetrical. The sac on the right side is entirely in $\mathrm{x}$. The sac on the left side is sharply constricted by $9 / 10$ so that the anterior third of the sac lies in ix. The vas deferens is coiled into a globular mass, nearly half the size of the testis sac, or that portion of the sac which lies in $\mathrm{x}$. The prostates have a finely granular surface, are slightly flattened or compressed anteroposteriorly, and stand erect in segment $x$. The vas deferens passes into the side of the prostate facing the nerve cord. The prostates are constricted as they pass into the parietes.

The ovarian chamber is closed dorsally. The ovisacs extend through seg-

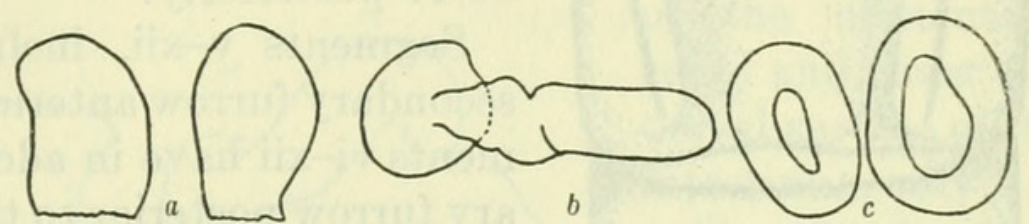

ment $\mathrm{xv}$. The spermathecal ampulla is small and nearly globular. The duct is coiled under the ampulla and slightly looped as it passes along the septum. In and just anterior to septum $7 / 8$, on the parietes in the region of $c d$, is a hard oval body. The atrium is attached to the roof of this body close to $7 / 8$. The specimen is too poorly preserved to permit an adequate determination of the relations between the structures involved in this region.

Distribution.-Moulmein (October).

Remarks. - The length varies from $80-105 \mathrm{~mm}$. and the diameter from $4-41 / 2 \mathrm{~mm}$. The ridges on $\mathrm{x}$ and $\mathrm{xi}$ seem to be characteristic. The ridges with the papillae project from the body wall $1 \frac{1}{2}-2 \mathrm{~mm}$. The gizzards are four in $\mathrm{xvii}-\mathrm{xx}, \mathrm{xviii}-\mathrm{xxi}$, or five in xvii-xxi.

In some specimens at least the finger or sac-shaped structure in vii passes into the oval glandular body on the parietes in and near $7 / 8$ and underneath the papilla on vii, and the surface of the papilla shows under high powers of the microscope two adjacent pores. 
The condition of the specimens is such as to prevent a determination of the relationship of the spermathecal duct to the gland and the atrial (?) sac in vii.

\section{NOTOSCOLEX BIRMANICUS Gates}

Notoscolex birmanicus Gates, Ann. Mag. Nat. Hist., ser. 9, vol. 19, p. 609, 1927.

Distribution.-Maymyo, F.S. S. Probably widely spread throughout the Shan Plateau.

Remarks.-There are four pairs of calciferous glands in this species in segments ix-xii. Through a misprint the original description stated that they occurred in "segments ix-xiii."

\section{NOTOSCOLEX DEPRESSUS, new species}

Description of the type-specimen, external characteristics (Cat. No. 19256, U.S.N.M.).-Length, $200 \mathrm{~mm}$. Diameter, 3-6 mm. Num-

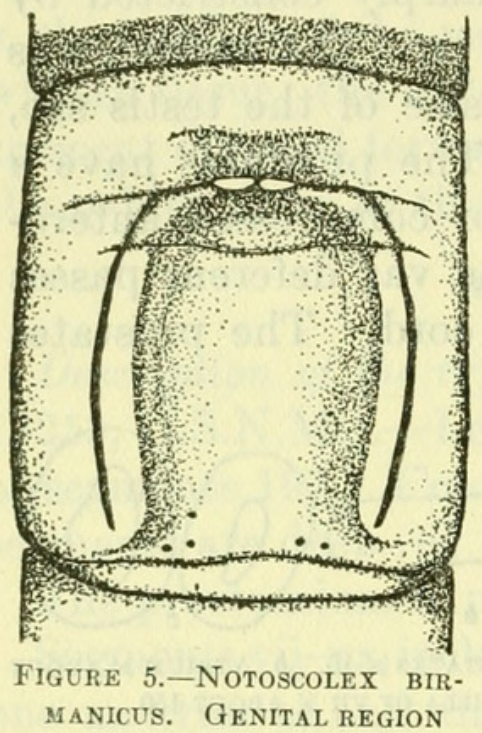
ber of segments, 334. Color: Unpigmented, very light grayish white color, except on the clitellum which is brownish red.

The prostomium is prolobous and withdrawn into the buccal cavity.

The first dorsal pore is in $9 / 10$. Pores are also present in $10 / 11,11 / 12,12 / 13$, and from $16 / 17$ posteriorly.

Segments $v$-xii, inclusive, have a deep secondary furrow anterior to the setae. Segments vi-xii have in addition a deep secondary furrow posterior to the setae. Segments viii and ix have a slighter tertiary furrow on the posterior third of the segments. There are numerous furrows on xvii and xviii. Segments behind xviii usually have two secondary furrows, one anterior to and one posterior to the setae.

The setae are eight for each segment and begin on ii. Anterior to the clitellum $a b$ is less than $c d$, and $a a$ is less than $b c$. Just posterior to the clitellum $a b$ is less than $c d$, and $a a$ is about equal to two $b c$. More posteriorly still, $a a$ and $b c$ become nearly equal.

The clitellum begins behind the setae of xii and extends to $16 / 17$ (about $4 \frac{1}{4}$ ), dorsal pores, except on $12 / 13$, and intersegmental furrows are lacking.

The male pores are not visible externally, but according to the dissection open in the region $b c$ on segment $\mathrm{xvii}$.

The female pores are minute paired slits on xiii, anterior and slightly internal to seta $a$ of the segment.

The spermathecal pores are in $6 / 7$ and $7 / 8$ in line with seta $c$. 
The only genital marking is a horseshoe-shaped ridge on xvii and xviii. The opening of the horseshoe is directed posteriorly. The arms of the horseshoe are in the region $b c$, nearer $b$ than $c$. The seminal grooves lie in this ridge, except anteriorly, where they turn off from the ridge and bend inwardly to end blindly on the anterior wall of the depression. The region within the ridge is depressed, the depression sloping more deeply anteriorly.

Internal anatomy.-Septa 6/7,7/8, 8/9, $9 / 10$, and $10 / 11$ are thickened, $11 / 12$ and $12 / 13$ are slightly thickened.

The gizzard is slightly elongated in vi. Paired calciferous glands are attached to the alimentary canal in segments ix, $x, x i$, and xii. The intestine begins in xiv.

The last pair of hearts is in xii. Paired commissures are also present in segments vi-xii.

The testes and male funnels are free in

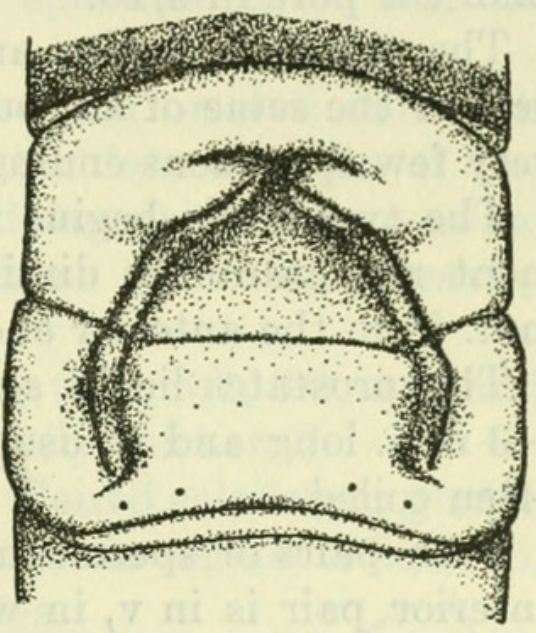

FiguRE 6.-NOTOSCOLEX DEPRESSUS.

GENitAL REgion segments ix and $x$. The seminal vesicles are small paired structures in $\mathrm{x}$ and $\mathrm{xi}$ on the posterior faces of the septa at the sides of the alimentary canal. The prostate extends through segments xvii-xxiv on the left side and xvii-xxiii on the right side. They lie at the sides
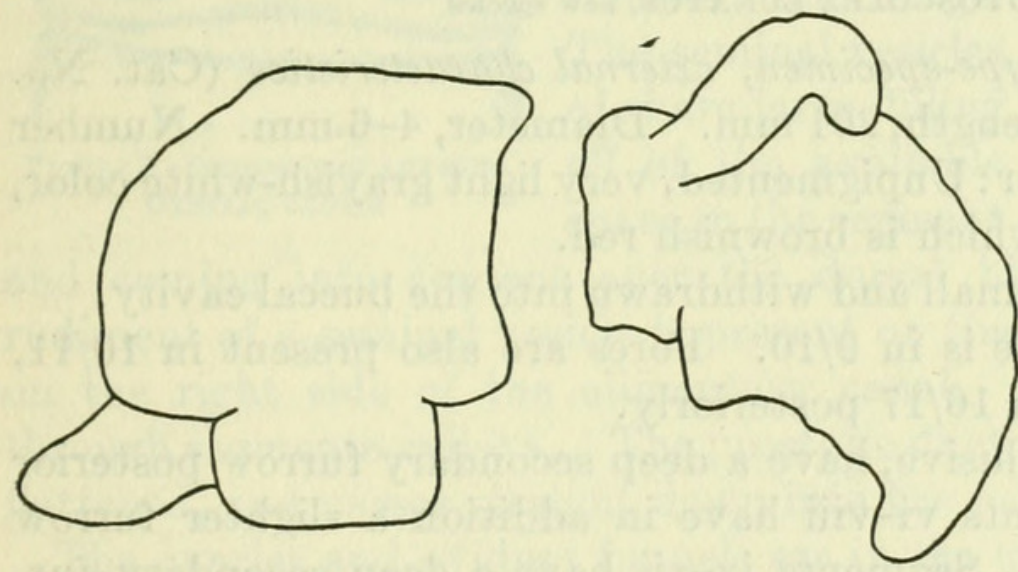

Figure 7.-Notoscolex depressus. Spermathecae $\times$ about 15 of the alimentary canal and cover the dorsal surface of the intestine only in xxiii and xxiv where the posterior end of the gland is bent upward so as to come into contact with the dorsal blood vessel. The prostatic duct is nearly straight, about three millimeters long, and slightly flattened. The prostates are rather thick and are slightly flattened laterally.

The ovaries and oviduct funnels are in the usual positions but in segment xii. Both pairs of spermathecae are in segment vi. The ducts of the posterior pair pass back through $6 / 7$ and vii and into the body wall in $7 / 8$. The ducts of the anterior pair pass into the body wall in $6 / 7$.

Distribution.-Maymyo, F. S. S. 
Remarks.-The length of other specimens varies from 190-215 $\mathrm{mm}$., and the diameter from 3-4 mm., at the posterior end, to 5-6 mm., at the thickest portion of the anterior end.

The prostomium is prolobous in all specimens in which it is visible.

In one specimen the first dorsal pore is in $8 / 9$, but is much smaller than the pore in $9 / 10$.

The clitellum begins anywhere in the region from $12 / 13$ to just behind the setae of xii, but practically always extends to $16 / 17$, in a very few specimens ending just behind the setae of xvi.

The typhlosole begins in the clitellar region, occasionally in segment xiv, gradually diminishes in size posteriorly and ends 85-90 $\mathrm{mm}$. from the anterior end.

The prostates lie in segments xvii-xxiv. The prostatic duct is $2-3 \mathrm{~mm}$. long and is usually straight, sometimes bent slightly, less often coiled.

Both pairs of spermathecae are usually in vi, but occasionally the anterior pair is in $\mathrm{v}$, in which case the ducts pass through $5 / 6$, vi, and into the body wall in $6 / 7$. The spermathecal duct is short and fairly stout. The ampulla is two to four times the length of the duct, club-, heart-, or irregularly shaped. The single short diverticulum is also rather variable. It may be a small wart-like projection from the spermathecal duct, or club-shaped, or more elongate and either straight or slightly bent at the free end.

\section{NOTOSCOLEX LUNATUS, new species}

Description of the type-specimen, external characteristics (Cat. No. 19262, U.S.N.M.).-Length, $201 \mathrm{~mm}$. Diameter, 4-6 mm. Number of segments 314 . Color: Unpigmented, very light grayish-white color, except the clitellum, which is brownish red.

The prostomium is small and withdrawn into the buccal cavity.

The first dorsal pore is in $9 / 10$. Pores are also present in $10 / 11$, $11 / 12,12 / 13$, and from $16 / 17$ posteriorly.

Segments iv-xii, inclusive, have a deep secondary furrow posterior to the setae. Segments vi-viii have in addition a slighter furrow anterior to the setae. Segments ix-xii have a deep secondary furrow anterior to the setae. On the ventral side of segments vi and vii there are numerous short furrows perpendicular to the intersegmental and secondary furrows.

There are eight setae to each segment in four pairs. The first setae are on segment ii. Anterior to the clitellum the setae are small and not easily seen, but $a b$ appears to be smaller than $c d$, and $a a$ less than $b c$. Just posterior to the clitellum $a b$ is very slightly less than $c d$, and $a a$ and $b c$ are about equal. More posteriorly $b c$ gradually diminishes and becomes smaller than $a a$. Similiarly $c d$ diminishes so that $a b$ and $c d$ become equal. 
The clitellum begins at $12 / 13$ and extends to $16 / 17(4)$. Intersegmental furrows and dorsal pores are lacking.

The male apertures are not visible externally.

The female pores are minute paired slits on an oval whitish area just anterior to and internal to the setal lines $a a$.

The spermathecal apertures are minute openings in $6 / 7$ and $7 / 8$ in line with $a$.

The only genital marking is a deep depression on xvii and xviii between the setal lines $b b$. Furrows on the lateral walls of the depression mark off an oval area on each side on which is the seminal groove. These grooves are crescentic in shape with the concavity facing anteriorly and outwardly.

Internal anatomy.-Septum $5 / 6$ is present, thin; $6 / 7,7 / 8,8 / 9$, and $9 / 10$ are thickened; $10 / 11$ and $11 / 12$ are slightly thickened.

The gizzard is slightly elongate in vi. Paired calciferous glands are present at the sides of the alimentary canal in segments ix, $x, x i$,

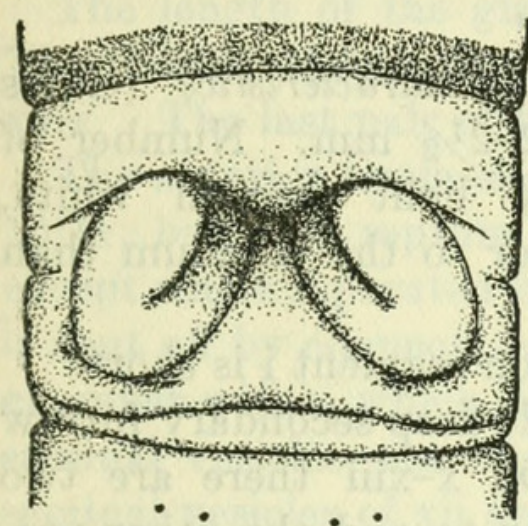

Figure 8.-Notoscolex lunatus. Genital REgion and xii. The intestine begins in xiv.

The last pair of hearts is in xii.

The testes and male funnels are free in $x$ and $x i$. The funnels are large. The seminal vesicles of xi are large, filling all of the available space in the segment

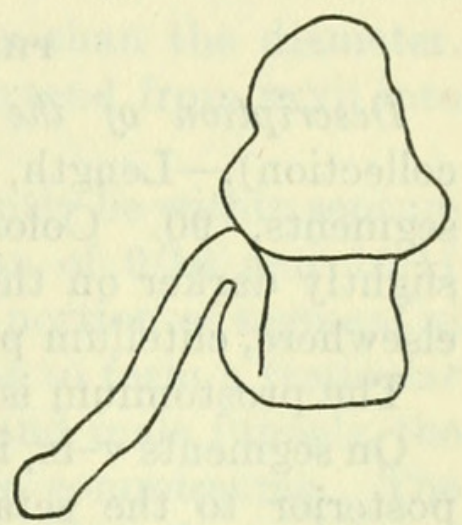

Figure 9.-Notoscolex LUNA TUS. SPERMATHECA $\times$ ABOUT 15

and coming into contact over the dorsal blood vessel. A small rudiment of a seminal vesicle is present on the posterior face of $9 / 10$ on the right side of the alimentary canal. The prostates extend through segments xvii-xx. The prostatic duct is short, thin, slightly flattened, and passes straight down into the parietes.

The ovaries and oviduct funnels are in the usual positions but in segment xii. The posterior pair of spermathecae is in vii and the anterior pair in vi.

\section{Distribution.-Maymyo, F. S. S.}

Remarks.- The length of other specimens varies from 155-205 mm. and the diameter from 3-4 $\mathrm{mm}$. posteriorly to $4-6 \mathrm{~mm}$. anteriorly.

The prostomium is epilobous but without the transverse furrow at the posterior edge of the tongue on segment $i$, in all specimens in which it is visible.

The first dorsal pore of all the specimens is in $9 / 10$.

The clitellum begins at $12 / 13$, or just behind the setae of xii, and ends just posterior to the setae of xvi or on $16 / 17$. 
All of the specimens except the type have a second large pair of seminal vesicles in segment $\mathrm{x}$ as well as xi. The prostates are flattened strap-shaped glands. The inner edge is straight, the outer edge incised, especially posteriorly. The duct is $1-2 \mathrm{~mm}$. long, thin, flattened, and passes straight into the parietes.

The spermathecal duct is stout. The diverticulum is longer than the ampulla and duct together, narrowly tubular, bent in various ways, and only very slightly enlarged at the free end. The ampulla is roughly heart-shaped.

In coloration and general external appearance this worm is very similar to $N$. depressus. The two forms are readily differentiated, however, by the setal intervals, and the character of the ridges bearing the seminal grooves. N. lunatus appears to be much rarer than the other species as only eight specimens were secured. Four of the eight are short, broken-off head portions. Fifty-eight specimens of the other species were secured.

PHERETIMA MINUTA, new species

Description of the type-specimen, external characteristics (Gates: collection).-Length, $43 \mathrm{~mm}$. Diameter, 2-21/2 mm. Number of segments, 90. Color: Unpigmented, very light grayish white, slightly darker on the dorsal surface anterior to the clitellum than elsewhere, clitellum pinkish.

The prostomium is epilobous, the tongue on segment $i$ is short.

On segments $v-i x$, inclusive, there is a single deep secondary furrow posterior to the setae of the segment. On $x$-xiii there are two secondary furrows per segment, one anterior to and the other posterior to the setae of the segment. The setae are on ridges which are marked off, behind the clitellum, by more or less complete secondary furrows.

The first dorsal pore is in $12 / 13$.

The setae begin on segment ii. The setal numbers are; $v-32, \mathrm{ix}-36$, xii-37, xix-36. As a rule there is no break in the setal circles in the ventral region and the dorsal break is very slight. The Iast three segments have no setae, and the fourth segment from the last has only six setae, all in the ventral region.

The clitellum extends from $13 / 14$ to $16 / 17$ (3). It is ring shaped and complete on all the segments. Dorsal pores and intersegmental furrows are lacking; on the ventral side of segment xvi there are four setae.

The male pores are on segment xviii at the center of small round papillae, separated by 10 setae. The papillae have flat surfaces distinctly marked off by a circumferential furrow and are seated on very slight conical swellings in the body wall in the setal circle.

The female pore is on a small whitish oval area on xiv. 
The spermathecal pores are four pairs in $5 / 6,6 / 7,7 / 8$, and $8 / 9$. There are 15 setae between the lines of the spermathecal apertures on viii.

The genital papillae are paired on vii, viii, and xix. On xx there is a single papilla on the right side just behind the papilla on xix. There are 4 setae on vii and viii between the centers of the papillae. There are 13 setae on segment xix between the centers of the papillae. The markings are small, round, and are located between the setae and the anterior furrow of the segiment. Each papilla consists of a gray concave spot surrounded by a definite whitish rim or lip.

Internal anatomy. $-4 / 5$ and $5 / 6$ are thin, $6 / 7$ and $7 / 8$ are slightly thickened, $8 / 9$ is represented only by a ventral vestige attached to the longitudinal sheet of tissue underneath the gizzard, $9 / 10$ may be partially fused with $10 / 11$ or is absent, 10/11, 11/12, 12/13, 13/14, and $14 / 15$ are very slightly thickened.

The length of the gizzard is slightly greater than the diameter. The intestine begins in xvi. Intestinal caeca extend from xxvii into xxiv. The last pair of hearts is in xiii.

The anterior testis-sacs are large and apparently lie within septum $10 / 11$, but this septum may represent a fusion of $9 / 10$ and $10 / 11$ except where separated by the testes. A large portion of segment xi $\mathbf{i}_{\mathrm{S}}$ shut off by connective tissue in such a way as to form a testicular chamber within which are enclosed the testes, and male funnels, the seminal vesicles, the alimentary canal, and the commissures. The seminal vesicles of xii are small, although larger than the vesicles of $\mathrm{xi}$ and are attached to the posterior face of $11 / 12$ at the sides of the alimentary canal. The prostates are highly lobulated glands extending through xvii-xix. The prostatic duct is about $11 / 2 \mathrm{~mm}$. long and is slightly looped.

The ovaries and oviduct funnels are in xiii as usual. The spermathecae are in segments vi-ix and open anteriorly.

Distribution.-Lashio and Maymyo, F. S. S.

Remarks.-The length, diameter, and segmental numbers vary only slightly as the figures below, of five worms chosen at random, show;

\begin{tabular}{|c|c|c|c|}
\hline & Length & Diameter & $\begin{array}{l}\text { Number } \\
\text { of seg- } \\
\text { ments }\end{array}$ \\
\hline $\begin{array}{l}a \\
a \\
b \\
c \\
c \\
d \\
e \\
e-1.0 .\end{array}$ & $\begin{array}{c}m m . \\
35 \\
38 \\
42 \\
42 \\
42\end{array}$ & $\begin{array}{c}m m \\
2-21 / 2 \\
21 / 2 \\
21 / 2 \\
3 \\
3\end{array}$ & $\begin{array}{l}86 \\
91 \\
83 \\
90 \\
90\end{array}$ \\
\hline
\end{tabular}

The first dorsal pore is in $12 / 13$ in all the specimens. 
There are 10 to 12 setae between the male papillae; 12 is the number found most frequently. There are 14 to 16 setae between the lines of the spermathecal pores on segment viii. Setae are always present on the ventral region of the last clitellar segment (xvi), the number varies from 2 to 7 . Setae are always lacking on the last 3 to 6 segments, and are usually few in number and confined to the ventral region on the last segment on which they occur.

The genital papillae are paired on one or more, or all, of segments vii, viii, xix, and $\mathrm{xx}$, and are always located on the anterior border of the segment. Unpaired median papillae of the same size and appearance are occasionally present on the anterior region of one or more of the segments just mentioned.

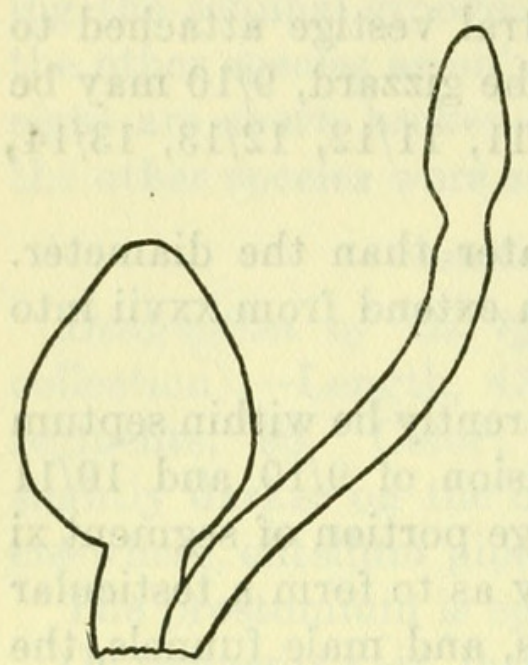

Figure 10.-Pheretima minuta. SPERMATHECA $\times$ about 14

The prostate is often smaller than in the type and is sometimes represented only by a few nodules on the ental end of the prostatic duct. When the prostate is vestigial the duct is usually quite straight.

The spermathecal ampulla is conical and more than twice as long as the duct from which it is sharply delimited. The narrow tubular diverticulum is longer than the duct and ampulla together and is constricted near the ental end. The short portion beyond the constriction is slightly thicker than the rest of the diverticulum. Frequently the diverticulum ectal to the constriction is longer than the duct and ampulla together. The figure is characteristic, the spermathecae varying from one worm to another only in the length of the diverticulum.

\section{PHERETIMA ORNATA, new species}

Description of the type-specimen, external characteristics (Cat. No. 19254, U.S.N.M.).-Length, $137 \mathrm{~mm}$. Diameter, 6-8 mm. Number of segments, 106. Color: Dorsally bluish gray, ventrally very light grayish. The clitellum is darker with a reddish-brown tinge.

The prostomium is epilobous, but the furrow at the posterior end of the prostomial tongue on segment $\mathrm{i}$ is lacking.

On segments ix-xiii there are two secondary furrows per segment, one anterior to and the other posterior to the setae. Posterior to the clitellum there are usually two furrows per segment similarly placed.

The first dorsal pore is in intersegmental furrow 11/12.

The setae begin on segment ii and are located on distinct ridges from iii on. No setae are visible on the clitellar segments. The 
numbers are $v ; 40$, ix; 48, xii; 60, xix; 68, xxxiv; 70. There is a slight dorsal and ventral break in the setal circles.

The clitellum extends from $13 / 14$ to $16 / 17(3)$. Dorsal pores and intersegmental furrows are lacking.

In the setal circle of xviii are two very slight conical swellings. Between these swellings there are 20 setae. At the tip of the swelling is a small round opening into a small concavity in the body wall. The lumen of the concavity is practically filled by a single, smoothsurfaced, cylindrical papilla which projects slightly beyond the edge of the opening into the concavity. At the tip of the papilla is the minute male pore. On the conical swelling there are four more or less complete concentric furrows, equidistant from each other and from the edge of the opening into the concavity.

The female pore is a single small opening at the center of an oval whitish area on xiv.

The spermathecal pores are in $7 / 8$ and $8 / 9$ about one-half of the circumference apart. There are 25 setae on segment viii between the lines of spermathecal pores.

The only further genital markings on this specimen are a pair of papillae on segment xviii. These structures are the same in size and appearance as those bearing the male pores. Each papilla is located on the edge of the conical swelling internal to the male pore and slightly anterior to the setae. Each has at the free end a small pore;

Internal anatomy. - Septa $5 / 6,6 / 7$, and $7 / 8$ are thickened; $8 / 9$ is missing; $9 / 10$ is not attached normally to the parietes, but is represented by a delicate sheet of tissue lying against $10 / 11$ in such a way as to inclose a small medio-ventral space containing the anterior testis-sacs and the vascular commissure of segment $x$. Septa $10 / 11,11 / 12,12 / 13$, and $13 / 14$ are thickened.

The gizzard is nearly spherical and occupies the spaces of segments vii, viii, and ix. The intestine begins in $x v$. The intestinal caeca extend from xxvii into xxiii on the right side and into xxii on the left side.

There are two pairs of commissures in the combination gizzard segment. The anterior pair passes to the gizzard. The right commissure of the next pair is atrophied. The commissures of $\mathrm{x}$ are not visible until $9 / 10$ is dissected off. The last pair of "hearts" is in xiii.

There are large nephridial masses dorso-lateral to the alimentary canal in $\mathrm{v}$ and $\mathrm{vi}$.

The anterior testis-sacs are on the anterior face of $10 / 11$ covered over by the rudiment of $9 / 10$. The posterior pair of testis-sacs are in the usual positions in xi. The paired seminal vesicles are in xi and xii, those of xii smaller than the ones in xi. The vesicles are not very large and are well down on the sides of the alimentary canal. The prostates are small and confined to xvii and xviii. Each gland 
has three or four large lobes marked off by deep incisions and each lobe is composed of several lobules. The duct is S-shaped and variously placed. Near the prostate on each side is a single gland with a duct which passes into the body wall and opens to the exterior through the pore on the tip of the papilla on xviii near the male pore.

The ovaries and oviduct funnels are in the usual positions in segment xiii. On the posterior face of $12 / 13$ at each side of the intestine is an elongate club-shaped structure that may be an ovisac. The two pairs of spermathecae lie in combination gizzard segment and open anteriorly. Near each spermatheca is a single glandular mass with a duct similar in appearance to the glands located near the prostates.

\section{Distribution.-Lashio, F. S. S.}

Remarks.-The length of other specimens varies from 120-140 mm., and the diameter from $5-6 \mathrm{~mm}$., at the posterior end, and $7-8 \mathrm{~mm}$., at the anterior end.

The posterior furrow at the end of the prostomial tongue on segment $i$ is lacking on all but one of the worms.

Two secondary furrows may be present on any segment posterior to $\mathrm{v}$.

The first dorsal pore is in $11 / 12$ in all of the worms. In many specimens the positions of the dorsal pores on the clitellum are indicated by pore-like depressions in the thickened epidermis, but in none of these worms are there functional pores on the clitellum.

The setal circles are usually without a ventral break; the dorsal break is small, about $2 y z$. The setae are located on distinct ridges.

The papillae bearing openings of the ducts of glands of the prostatic region are usually absent and when present vary in number. Three specimens have a pair of such papillae as in the type. Two have two pairs, the second pair posterior to the setae. One worm has one papilla on the right side. The pore bearing papillae are placed so as to occupy the entire space between two consecutive furrows on the slope of the conical swelling.

The number of setae between the male papillae varies from 18-24, 21 the number most commonly found. The number of setae on viii between the lines of the spermathecal pores varies from 23-28, 24, 25 , or 26 , the numbers most commonly found.

Setae from various dorsal and ventral positions anterior to the clitellum and various ventral positions posterior to the clitellum were examined microscopically. All such setae have ornamented outer ends, the ornamentation consisting of short transverse rows of very fine teeth.

The last 10 septa are much thickened in all specimens examined.

The ventral edges of the intestinal caeca are incised or lobed in such a way as to form ventrally projecting secondary caeca. The 
typhlosole is simple: it begins in the region of xxvii and ends gradually 10 to 15 segments from the posterior end.

The commissure belonging to the left side of segment ix is atrophied in all specimens. The commissures of $\mathrm{x}$ and $\mathrm{xi}$ as well as the right commissure of ix pass into the ventral vessel. On each side of the dorsal vessel in the posterior part of the segment, from about the middle of the worm posteriorly, is a small glandlike body. Smaller and more transparent glands are similarly attached to the dorsal vessel anteriorly.

The vasa deferentia of a side come into contact and join in the posterior part of segment xii.

The club-shaped bodies (ovisacs?) from the posterior surface of $12 / 13$ were examined microscopically but no ova were found.

The spermathecal duct is short and sharply delimited from the ampulla which is about two to two and one-half times as long as

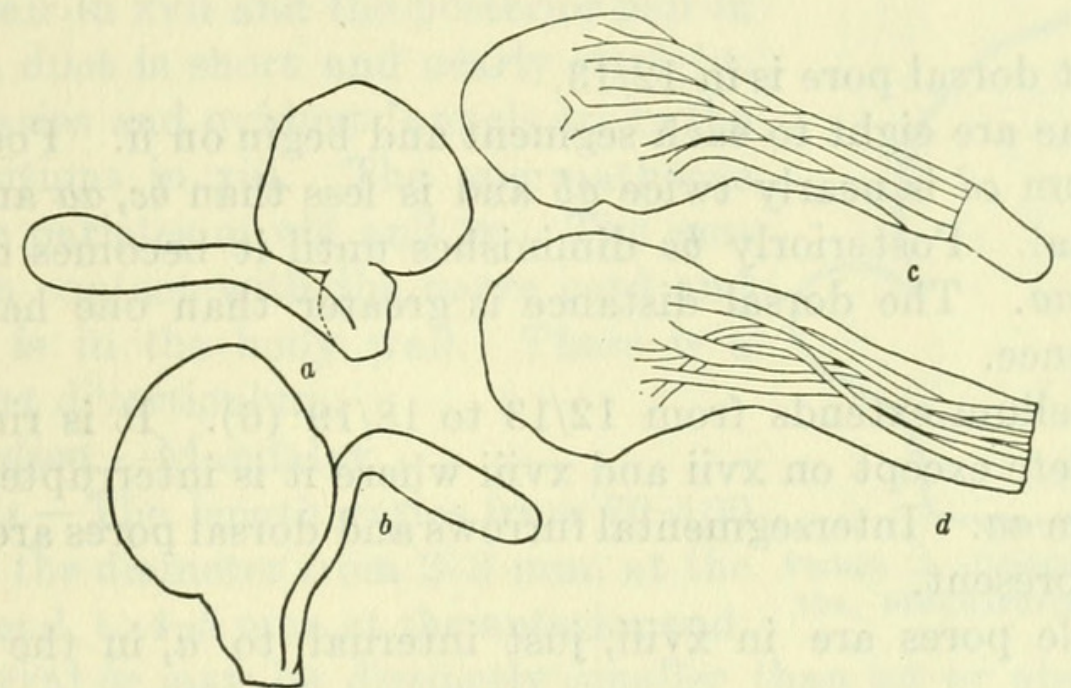

Figure 11-Pheretima ornata. $a, b$. Spermathecae $\times$ about $8 . c$. Gland from the prostatic region $\times$ about 20 . d. Gland from the SPERMATHECAL REGION $\times$ ABOUT 27

the duct. The ampulla is usually more or less heart-shaped. The diverticulum consists of a duct more than twice as long as the spermathecal duct and an ental enlargement which is usually round (fig. 11a) but which may be occasionally much elongated (fig. 11b). Intermediate conditions are found.

The glandular masses located near the spermathecae and the prostates are very similar in appearance when examined in glycerine. Those from the prostatic region (fig. 11c) are one and one-half to two times the size of those from the spermathecal region (fig. 11d). The ental end of the gland is roughly ovoid and the stalk consists of transparent tissue in which lie 6-10 ducts.

Only one species of Pheretima with spermathecal pores in $7 / 8$ and $8 / 9$ has been recorded from India up to the present time and this form (P. andamanensis Michaelsen 1907) is quite evidently different from the worm just described. The literature on the genus Pheretima is 
extensive and widely scattered and some is not available to the writer. There is, therefore, a possibility that the species just described above is not new.

OCTOCHAETUS LUNATUS, new species

Description of the type-specimen, external characteristics (Cat. No. 19255, U.S.N.M.).-Length, $94 \mathrm{~mm}$. Diameter, 3-5 mm. Number of segments, 167. Color: Very light grayish, except the clitellum, which is reddish.

The prostomium is prolobous.

On segments $v$-xii there is a deep secondary furrow posterior to the setae of the segment. On segments vii-xi there is a secondary furrow anterior to the setae of the segment. On segments vii-ix there is a slight tertiary furrow on the posterior third of the segment. Posterior to the clitellum there are usually two secondary furrows per segment, one anterior to and one posterior to the setae of the segment.

The first dorsal pore is in $12 / 13$.

The setae are eight to each segment and begin on ii. Posterior to the clitellum $c d$ is nearly twice $a b$ and is less than $b c, a a$ and $b c$ are about equal. Posteriorly $b c$ diminishes until it becomes distinctly less than $a a$. The dorsal distance is greater than one half of the circumference.

The clitellum extends from $12 / 13$ to $18 / 19$ (6). It is ringshaped and complete except on xvii and xviii where it is interrupted by the male area in $a a$. Intersegmental furrows and dorsal pores are lacking. Setae are present.

The male pores are in xviii, just internal to $a$, in the seminal grooves.

The female pores are paired in $a a$ on xiv, each pore at the center of a minute transversely oval papilla, the two papillae contiguous at the center.

The spermathecal pores are paired in $a a$ on viii and ix, in line with the eight setae of the segment. They are about the same size and as readily visible as the female pores.

The only genital markings are the seminal grooves which extend across xviii onto the anterior portion of xix and the posterior portion of xvii. The grooves are crescent-shaped and just internal to $a$. The body wall between the two grooves is whitish.

Internal anatomy. - Septum $4 / 5$ is present and thickened; $5 / 6,6 / 7$, and $7 / 8$ are absent; $8 / 9,9 / 10,10 / 11$, and $11 / 12$ are thickened and very close together; $12 / 13$ is very slightly thickened. Septa $10 / 11$ and $11 / 12$ are bound together by a connective tissue in such a way as to close off a central portion of segment xi as a sort of testicular chamber which must be opened before the contents can be seen. 
The diameter of the gizzard is nearly twice the length. The calciferous gland of the left side is almost entirely in $\mathrm{xv}$, the gland of the right side is in xvi. The glands are large, dark red, and flattened antero-posteriorly. The intestine begins in xvii.

The last pair of hearts is in xiii. There are three pairs of commissures belonging to segments vi, vii, and viii posterior to the gizzard under $8 / 9$; anterior to the gizzard and just posterior to $4 / 5$ is another pair of commissures, belonging to segment $\mathrm{v}$. The dorsal vessel passes through $4 / 5$ and anteriorly.

There is a large mass of nephridia dorso-lateral to the alimentary canal in iv.

The testes and male funnels are in $\mathrm{x}$ and $\mathrm{xi}$, the funnels of $\mathrm{xi}$ slightly larger than the funnels of $x$. The seminal vesicles are small and attached to the posterior face of $11 / 12$ at the sides of the alimentary canal. The prostates are small and flattened, the anterior pair in xvii and the posterior pair in xix. The duct is short and nearly straight.

The ovaries and oviduct funnels are in the usual positions in xiii. The spermathecae are on the parietes of viii and ix. The ampulla is in contact with the nerve cord and the duct is in the body wall. There is a single short diverticulum.

\section{Distribution.-Mandalay.}

Remarks.-The length varies from 70-100 mm., and the diameter from $2-3 \mathrm{~mm}$. at the Figure 12 .-Octochaetus lunaposterior end, to $4-5 \mathrm{~mm}$. at the anterior end.

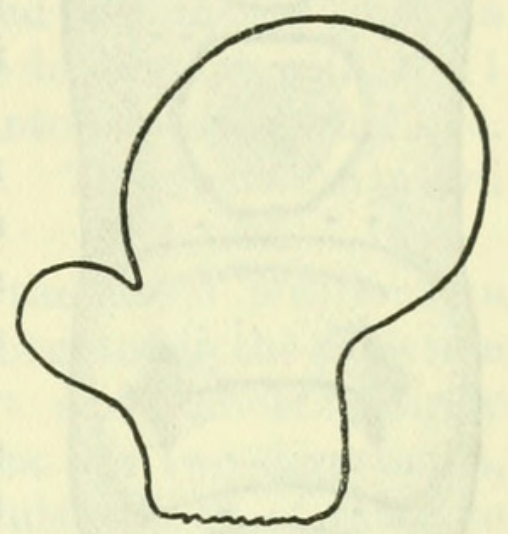
Setal interval $b c$ may be distinctly smaller than $a a$ or about equal to $a a$.

The prostates are $2-5 \mathrm{~mm}$. long, and the duct is $1 / 2-3 / 4 \mathrm{~mm}$. long.

EUTYPHOEUS BIFOVIS, new species

Description of the type-specimen, external characteristics (Cat. No. 19257, U.S.N.M.).-Length, $240 \mathrm{~mm}$. Diameter, 6-8 mm. Number of segments, 197. Color: Deep rich brown.

The prostomium is prolobous.

On segments ii to xii, inclusive, there is a deep secondary furrow, posterior to the setae of the segment. On segment $\mathrm{v}$ there is in addition a slighter furrow, posterior to the setae. On segments vi to xii, inclusive, there is a deep furrow posterior to the setae. On ix and $\mathrm{x}$ there is a slighter tertiary furrow on the anterior and posterior thirds of the segments, while on xi and xii there is a single tertiary slight furrow on the posterior third only. Segment xiii has a single deep secondary furrow anterior to the setae. Posterior to the 
clitellum there are on many of the segments two slight secondary furrows, one anterior to and the other posterior to the setae of the segment.

The first dorsal pore is in 10/11. Dorsal pores are also present in $11 / 12$ and from $17 / 18$ posteriorly. There are pore like depressions in $12 / 13$ to $16 / 17$ but no functional pores are present in these furrows.

The setae are eight to each segment, in four pairs, and begin on ii. Anterior to the clitellum $a b$ is about equal to $c d$, and $b c$ and $a a$ are about equal. Posterior to the clitellum $a b$ is less than $c d$, and $b c$ is less than $a a$. Toward the tail $a b$ and $c d$ tend to become equal, but

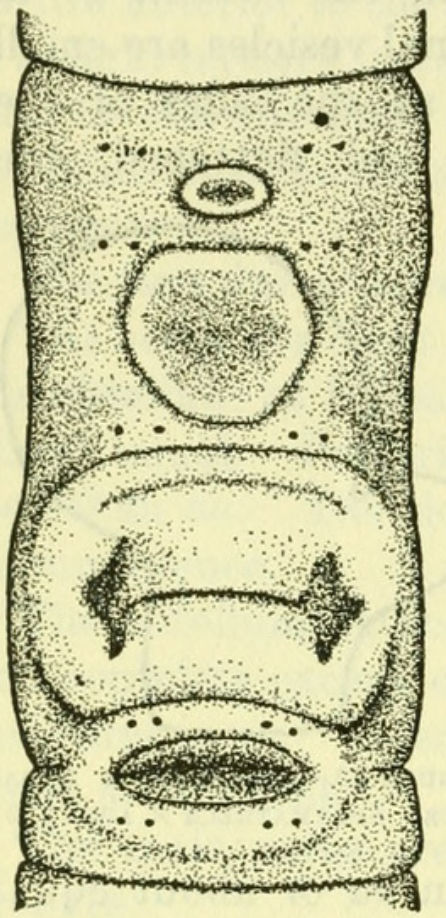

Figure 13.-EUtyphoeus bifovis. Genital area $a a$ remains larger than $b c$. The dorsal distance is slightly greater than one-half the circumference.

The clitellum extends from $13 / 14$ to $17 / 18$ (4). There are no intersegmental furrows visible between the clitellar segments.

The male pores are on xvii in $b c$, just external to $b$. Each pore is on the center of a smooth, glistening, flat-topped area which lies at the bottom of a deep longitudinal depression in the region $a b$ on segment xvii.

The female aperture is single, on the left. side only, anterior to and very slightly internal to seta $a$.

The spermathecal pores are one pair in $7 / 8$ in the region $c d$.

There are three genital markings. The anteriormost is a circular area between setae $a b$ of segments $\mathrm{xv}$ and $\mathrm{xvi}$ and extending at the middle to just beyond the setal lines $b$. This area is concave, lighter in color than the rest of the clitellum, and sharply delimited by a circumferential furrow. An area similarly colored and delimited and also concave, but oval in shape lies across 18/19 from the setae of $x$ viii to the setae of xix and included between the setal lines $b b$. The long axis of the oval area is perpendicular to the long axis of the animal. The other marking is an oblong-shaped, whitish region extending from the setae of xvi to the setae of xviii, with the longer axis of the region along the long axis of the worm. The area is sharply delimited by furrows only on the anterior and posterior margins. In the region $a b$ on each side is a deep longitudinal depression into the body wall.

Internal anatomy.-Septa $4 / 5$ and 5/6 are present and thickened, the latter more than twice the thickness of the former; $6 / 7$ and $7 / 8$ 
are absent; $8 / 9,9 / 10$, and $10 / 11$ are much thickened and displaced backward together; $11 / 12$ is represented only by thin connective tissue which forms the median testicular chamber. The remaining septa are thin and attached normally.

The gizzard is bell-shaped with a posterior flange. There are calciferous glands in the wall of the alimentary canal in segment xii. The intestine begins in $\mathrm{xv}$.

The supra-pharyngeal and sub-pharyngeal ganglia are bright yellow but the circum-pharyngeal connectives, the nerves, and the ventral nerve cord are whitish as usual.

There are large tufted masses of nephridia adherent to the parietes in segment iii.

There are two pairs of vascular commissures under septum 8/9. The last pair of "hearts" is in segment xiii. The commissures of xi lie within the testicular chamber on the posterior face of 10/11.

The testes and male funnels are included within the median testicular chamber. The seminal vesicles are in contact with 10/11 anteriorly and posteriorly push $12 / 13$ back into contact with 13/14. The prostates are in $\mathrm{xviii}-\mathrm{xx}$, and are tubular. The ducts are in $\mathrm{xvii}$ and are coiled into an $\mathbf{S}$ shape.

The ovaries and oviduct funnels are in the usual positions in segment xiii. The spermathecal ampulla is elongated in the direction of the main axis. The duct is very short and almost entirely confined to the body wall. Each spermatheca has two diverticula, one on each side of the duct. The diverticula consist of three to seven seminal chambers arranged together as an elongate row or as a club-shaped body, and are nearer together posteriorly than anteriorly.

There are glandular thickenings of the ventral parietes in the region of the anterior and posterior genital markings.

Distribution.-Mandalay.

Remarks.-The length of the other specimens varies from 180-245 $\mathrm{mm}$., and the diameter from $6-8 \mathrm{~mm}$.

The first dorsal pore is usually in $17 / 18$, rarely in $13 / 14$, although nonfunctional porelike depressions occur between $10 / 11$ and $17 / 18$.

The clitellum begins at $12 / 13$ or somewhere between $12 / 13$ and $13 / 14$ and always extends to $17 / 18$.

Two worms have a genital marking on $14 / 15$ between setal lines $a a$, which is light in color, concave, but not as sharply delimited as the other two similar areas.

The typhlosole begins in the region immediately behind the clitellum and ends $65-70 \mathrm{~mm}$. from the posterior end of the worm in the region of the supra-intestinal glands. These glands are 12 pairs, 2 pairs in each of 6 successive segments.

The oviduct funnels are small and have thick rounded rims. 
The vasa deferentia are looped in xii and xiii and then pass straight back into xviii and under the prostatic ducts. Each vas deferens then bends in toward the nerve chord and is enlarged into an eggshaped body which is buried in the parietes just behind the prostatic duct. The prostatic duct is usually $14-15 \mathrm{~mm}$. long. The prostates are $55-65 \mathrm{~mm}$. long.

The penial setae are $3 \mathrm{~mm}$. or less in length, 15-25 micra thick near the tip, and 35-40 micra thick at the place of greatest enlargement near the inner end. The shaft is curved into a slight suggestion of a spiral but is flattened out by pressure of the cover glass into a wide arc. The tips of most of the setae examined are either missing or obviously deformed or softened. In the few undamaged setae the tip is bent slightly and hollowed out into a spoon shape. The ornamentation begins very close to the tip, extends $0.4-0.5 \mathrm{~mm}$. along the shaft, and consists of numerous ridges of very fine teeth. The

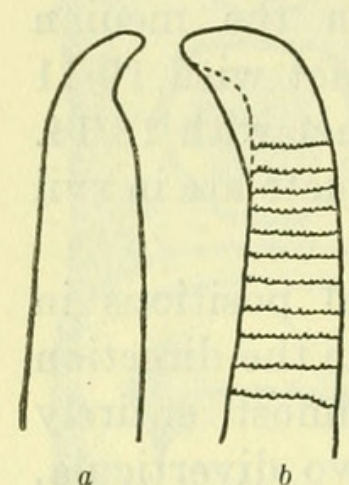
Figure 14.-EUTYPHO.
EUS BIFOVIS. $a$. PE.IAL SETA $\times$ ABOUT 450 . b. Penial seta $\times$ ABOUT 475 teeth are close together and the rows of teeth are not frequently broken and are fairly regularly spaced.

The clitellar and preclitellar setae have ornamentation similar to that on the penial setae, but the toothed ridges are more frequently broken and farther apart and not so regularly spaced.

\section{EUTYPHOEUS CONSTRICTUS, new species}

Description of the type-specimen, external characteristics (Cat. No. 19261, U.S.N.M.).-Length, 122 $\mathrm{mm}$. Diameter, 4-6 mm. Number of segments, 224. Color: Very light grayish white, except the clitellum which is reddish.

The prostomium is prolobous and partially withdrawn into the buccal cavity.

On segments iv-xii there is a deep secondary furrow posterior to the setae of the segment. On vi-xii there is a deep secondary furrow anterior to the setae of the segment. There are slight furrows on xiii anterior to the setae. Posterior to the clitellum there are two slight secondary furrows per segment.

The first dorsal pore is small and is in 10/11. Pores are also present in $11 / 12,12 / 13,13 / 14,16 / 17$, and posteriorly. There are nonfunctional pore-like depressions in 14/15 and 15/16.

The setae are eight to each segment and begin on ii. They are fine and in places on the anterior segments are retracted into the body wall. Behind the clitellum $a b$ is about equal to one-half of $c d, b c$ is greater than $c d$ and less than $a a, d d$ is greater than one-half of the circumference.

The clitellum extends from just anterior to the setae of xiii to $17 / 18\left(4 \frac{1}{2}\right)$. It is ring shaped and complete except on the ventral 
portion of xvii where it is interrupted by the male area. Setae are present except $a b$ of xvii. Intersegmental furrows are lacking.

The male apertures are transverse slits in $a b$ on xvii.

The female pores are paired diagonal slits on xiv anterior and just internal to seta $a$.

The spermathecal pores are in $7 / 8$, large. The body wall around the pore is swollen and fissured.

The only genital marking is a slight, dumb-bell shaped elevation on xvii, in $c c$. Much of the anterior edge is straight, the posterior edge impinges on the anterior portion of xviii. In $a b$ on each side is a slight conical elevation on which are located the male apertures.

Internal anatomy. - Septa $4 / 5$ and $5 / 6$ are thickened, especially $5 / 6 ; 6 / 7$, and $7 / 8$ are missing, $8 / 9,9 / 10,10 / 11$ are thickened and displaced backwards to-

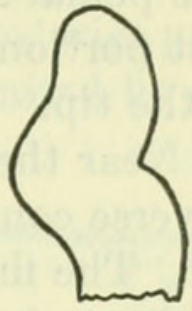

FigURE 16.-EUTYPHOEUS CONSTRICTUS. SPERMaTHECAL DIVERTICULUM $\times$ ABOUT 14 gether; $11 / 12$ is missing or represented only by a ventral vestige.

The gizzard is wider than it is long. Calciferous glands are embedded in the wall of the alimentary canal in segment xii. The intestine begins in $\mathrm{xv}$.

There are three pairs of commissures in the gizzard segment, one pair anterior to the gizzard and two pairs posterior to the gizzard under $8 / 9$. The last pair of hearts is in xiii. The supra-intestinal glands are in six successive segments about $55 \mathrm{~mm}$.

Figure 15.-Eutyphoeus CONSTRICTUS. PENIAL SETA, DRAWN FROM A MICROPHOTOGRAPH from the anterior end of the worm. The last pair of glands is much enlarged and very dark red in color.

There are tufted masses of nephridia adherent to the parietes of segment iii.

The testes and male funnels are enclosed in a median testicular chamber. The seminal vesicles extend from $10 / 11$ to $12 / 13$, pushing $12 / 13$ and $13 / 14$ into contact with $14 / 15$. There is a small pair of male funnels on the anterior face of $10 / 11$. The prostates extend through xvii and xviii. The duct is short and looped twice. The vasa deferentia come into contact in xiii and run posteriorly side by side without fusion, into xviii. The fused deferent duct is enlarged as it passes into the parietes immediately behind the penial setae.

The ovaries and oviduct funnels are in the usual positions in xiii. The spermathecal ampulla is firm and stands erect in the segment. The duct is short and practically confined to the body wall. There are two diverticula, one on each side of the duct. 


\section{Distribution.-Meiktila.}

Remarks. - The length varies from 110-130 mm., the diameter from 3-4 mm., at the posterior end to $6-7 \mathrm{~mm}$. at the anterior end. In a few specimens the first dorsal pore is large and located in 11/12.

The prostates are $21-25 \mathrm{~mm}$. long, the duct is $2-4 \mathrm{~mm}$. long. The spermathecal diverticula have a wide variety of shapes. In one specimen the diverticulum on one side of the duct may be elongate and finger shaped, while the diverticulum on the other side of the duct is club shaped with numerous small nodules on the end.

The penial setae are 1.5-1.8 mm. long; 48-52 micra thick at the widest portion of the base, and 48-65 micra thick at the widest region near the tip. The shaft is straight except for a single bend near the tip. Near the free end of the seta there are two or three distinct, transverse constrictions or grooves completely continuous around the shaft. The first $0.5-0.7 \mathrm{~mm}$. of the tip end of the seta is ornamented with short rows of teeth. The rows are quite regularly and fairly closely spaced.

EUTYPHOEUS EXCAVATUS, new species

Description of the type-specimen, external characteristics (Cat. No. 19260, U.S. N.M.).-Length, $274 \mathrm{~mm}$. Diameter, 6-10 mm. Number of segments, about 254 .

Color: Deep rich brown. The prostomium is prolobous, large.

On segments ii-xii there is a deep secondary furrow posterior to the setae of the segment. On iv-xii there is a deep secondary furrow anterior to the setae of the segment. Tertiary furrows are present as follows: vi, one on the posterior third; vii, one on the posterior third; viii, two on the posterior third; ix, one on the anterior third and two on the posterior third; $x$, one on the anterior third and one on the posterior third; xi and xii, one on the posterior third. On xiii there is one furrow anterior to the setae. Behind the clitellum nearly every segment has two deep secondary furrows, one anterior and one posterior to the setae. Many of the segments have a tertiary furrow on the anterior and posterior thirds formed by the secondary furrows.

The first dorsal pore is in $11 / 12$. Pores are present in $12 / 13,17 / 18$, and posteriorly.

There are eight setae and they begin on segment ii. Posterior to the clitellum $a b$ and $c d$ are about equal, $b c$ is less than $a a, d d$ is greater than one-half of the circumference.

The clitellum extends from the secondary furrow anterior to the setae of xiii to $17 / 18$ (about $41 / 2$ ). Intersegmental furrows and dorsal pores are lacking. The clitellum is interrupted ventrally by the genital markings and the depression on xvii. 
The male pores are in line with or very slightly external to $b$ at the center of white glandular areas at the bottom of the depression on xvii.

The female pore is single, anterior and very slightly internal to $a$, on the center of a small, oval, whitish area on the left side of xiv.

The spermathecal apertures are in $7 / 8$ in line with $b$.

The genital markings are the deep depression on xvii and two bluntly oval, large, median papillae on $14 / 15$ and 15/16. These papillae are whitish, smooth-surfaced, slightly concave areas which extend externally to just beyond the line $b$, and antero-posteriorly nearly to the setae of the segments concerned. The posterior papilla is slightly smaller than the anterior, and both are delimited by sharp circumferential furrows. On xvii is a transversely elongate slit in $c c$ opening into a depression in the parietes $2-3 \mathrm{~mm}$. deep. The body wall around the aperture is swollen, especially around the ends of the slit. On the anterior and the posterior walls of the depression, in the region $b b$, are paired smooth-surfaced glandular areas. Columnar porophores, present in closely related Burmese species of the genus, are entirely lacking here.

Internal anatomy. - Septa $4 / 5$ and $5 / 6$ are present and much thickened, especially $5 / 6$; $6 / 7$ and $7 / 8$ are absent; $8 / 9,9 / 10$, and $10 / 11$ are thickened and displaced backwards together; $11 / 12$ is absent or is represented only by the connective tissue forming the wall of the

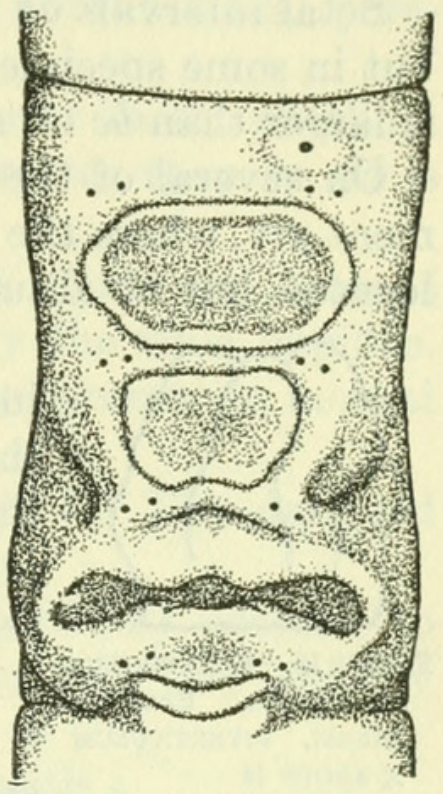

Figure 17.-EutrPhoEUS EXCAvatus. Genital region testicular chamber. This chamber is in the shape of a $U$ inverted over the alimentary canal.

The diameter of the gizzard is slightly greater than the length; there is a slight rim on the posterior end. There are calciferous glands in the wall of the alimentary tract in xii. The intestine begins in $\mathrm{xv}$.

There are large tufted masses of nephridia adherent to the parietes of segment iii.

The dorsal blood vessel ends with the more anterior of the two pairs of commissures under $8 / 9$. The last pair of hearts is in xiii.

The testes and male funnels are in the testicular chamber. The seminal vesicles are large, extending from $10 / 11$ to $12 / 13$ which is pushed back into contact with 13/14. The tubular prostates extend through xviii-xx and xviii-xxi. The duct is long and looped in xvii and xviii.

The vas deferens passes under the prostatic duct, turns in toward the nerve cord, and is enlarged as it passes into the parietes. 
The ovaries and oviduct funnels are in the usual positions in segment xiii. The spermathecal ampulla is large, flattened out dorsally by the gizzard. The duct is short and practically confined to the body wall. The single diverticulum is on the outer side of the duct and consists of four elongate, finger-shaped seminal chambers placed side by side.

The parietes are thickened in the region of the median genital markings.

Distribution.-Meiktila (October).

Remarks.-The length varies from 190-280 mm. The first dorsal pore is in 11/12 in all specimens. The clitellum begins just anterior or just posterior to the setae of xiii and extends to $17 / 18$.

Setal intervals $a b$ and $c d$ vary somewhat, $a b$ and $c d$ usually equal, but in some specimens $a b$ is noticeably smaller than $c$. Interval $a a$ is larger than $b c$ on all the worms.

On several of the specimens there is a minute depression on segment xiv, where the female pore of the right side would ordinarily be located, but no actual pore can be seen.

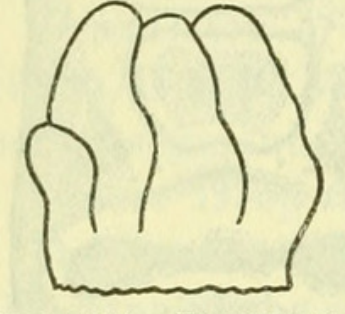

Figure 18.-Eutyphoeus excavatus. SPERMaTHECAL DIVERTICULUM $\times$ ABOUT 14

The genital markings are quite characteristic, just one worm from a large number differing from the type. In the exceptional specimen there is a third genital papilla, about the same size as the posterior marking, located between the setae of segments xiii and xiv.

There are 12 pairs of supra-intestinal glands in 6 successive segments about $85-95 \mathrm{~mm}$. from the anterior end.

The prostatic duct is $14-16 \mathrm{~mm}$. long.

The spermathecal ampulla is variously shaped and often consists of three to seven elongate seminal chambers arranged as in the type specimen. Frequently the chambers are round, more numerous, and so arranged on the free end of the diverticulum as to produce a berrylike appearance.

The penial setae are 4-5 $\mathrm{mm}$. long, 46-54 micra thick near the base, and 48-52 micra thick near the tip. The shaft has two long curvatures, the concavity of the first half of the seta on the opposite side from the concavity of the second half. The ornamentation consists of short rows of three to five teeth, or of single teeth scattered over the first $0.8-0.9 \mathrm{~mm}$. of the tip.

EUTYPHOEUS HASTATUS, new species

Description of the type-specimen, external characteristics (Cat. No. 19259, U.S.N.M.).-Length, $92 \mathrm{~mm}$. Diameter, 2-4 mm. Number of segments, 211. Color: Grayish, except the clitellum which is deep brownish red. 
The prostomium is prolobous, large.

On segments iv-xii, inclusive, there is a deep secondary furrow posterior to the setae of the segment. On segments vi-xii there is a second deep furrow posterior to the setae of the segments. On viii there are two slight tertiary furrows, one on the anterior third and one on the posterior third of the segment. On ix there are two slight tertiary furrows on the anterior third and one on the posterior third of the segment. On x there is a single tertiary furrow on the anterior third of the segment. Posterior to the clitellum there are two secondary furrows per segment, one just anterior to and the other just posterior to the setae.

The first dorsal pore is in $10 / 11$. Pores are also present in $11 / 12$, $12 / 13,13 / 14,17 / 18$ and posteriorly. There is a nonfunctional porelike depression on $16 / 17$.

The setae begin on ii, and are paired. Posterior to the clitellum $a b$ is less than $c d$ which is less than $b c, a a$ is greater than $b c, d d$ is greater than one half of the circumference.

The clitellum begins just anterior to the setae of xiii and extends to $17 / 18$. It is interrupted ventrally on xvii by the male papillae. Intersegmental furrows are lacking. All setae are present in normal positions except $a b$ on xvii.

The male apertures are on xvii, just external to $b$. Two dark red setae project through each aperture.

The female pores are on xiv. The right pore is just anterior to seta $a$, the pore on the left side is anterior to and very slightly internal to $a$.

The spermathecal apertures are in $7 / 8$ in line with $c$.

The paired male papillae are oval, sharply delimited, and slightly slantwise so that the anterior ends point toward each other. Each papilla extends from just internal to $a$, nearly to $c$. On the posterior part of the marking is a slight conical elevation bearing at the tip the male pore. Two sharply delimited oval papillae lie in $a a$ on xviii.

Internal anatomy.--Septa $4 / 5$ and $5 / 6$ are present and thickened; $6 / 7$ and $7 / 8$ are absent; $8 / 9,9 / 10$, and $10 / 11$ are thickened and displaced posteriorly, close together; $11 / 12$ is very thin and attached to the parietes ventrally and laterally close to $10 / 11$, dorsally the two septa are in contact so that the seminal vesicles appear to be in contact with $10 / 11$; the remaining septa are thin and attached normally.

The gizzard nearly fills segments vi-viii. There are calciferous glands in the wall of the alimentary canal in xii. The intestine begins in $\mathrm{xv}$.

There are nephridial masses on the parietes in the region of segment iii. 
There are three pairs of commissures in the combined gizzard segment, two under $8 / 9$ posterior to the gizzard, and one just behind $5 / 6$, anterior to the gizzard. The dorsal vessel continues anteriorly through iv and $v$. Lateral commissures are also present in segments ix-xiii.

The anterior pair of testes and funnels are free in $\mathrm{x}$. Segment $x i$ is reduced in size by the nearness of $10 / 11$ and $11 / 12$, ventrally, and their apposition and fusion (?) dorsally. The reduction is increased by the presence laterally of delicate connective tissue between the two septa. When the worm is first opened from the dorsal side, the segment is not at first noticeable, as only three septa are visible between the gizzard and 12/13. The last of these septa appears to be much thicker than the other two. The apparent thickness of the septum is due to the presence between $10 / 11$ and $11 / 12$ of testicular material of the same color as the septa. After cutting open the roof of the testicular chamber $11 / 12$ can be traced

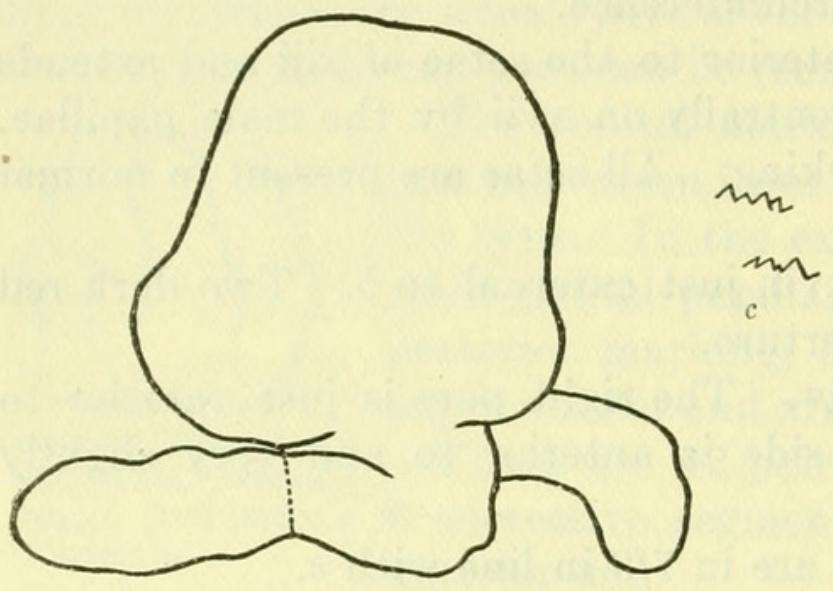

$a$

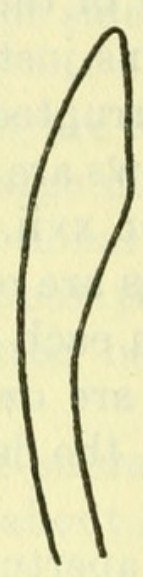

$b$

Figure 19.-Eutyphoeus hastatus. $a$. Spermatheca $\times$ about 16 . $b$. TIP OF PENIAL SETA $\times$ aBOUT 91 . c. ORNAMENTATION OF PENIAL SETA, OIL IMMERSION

to the parietes ventro-laterally and ventrally. On the floor of the chamber is the second pair of male funnels. The anterior pair of seminal vesicles is in ix, the vesicles are small and lobed. The posterior vesicles are much larger, extending from $10 / 11$

to $12 / 13$, pushing $12 / 13$ and $13 / 14$ into contact with $14 / 15$. The prostates are small, tubular, and extend through xvii-xx. The duct is in xvii, short, and looped once or twice.

The ovaries and oviduct funnels are in the usual positions in xiii. The single pair of spermathecae is in the combined gizzard segment.

Distribution.-Prome, Thayetmyo.

Remarks.-Length 85-95 mm. Diameter, 2-21/2 mm. posteriorly to $4-5$ anteriorly. The first dorsal pore is in $10 / 11$ in all specimens. Setal interval $a a$ varies from $1 \frac{1}{2}-2 b c$. The spermathecal pores are in $b, c$, or between $b$ and $c$.

The unpaired median papillae are in the region $a a$, extending anteriorly and posterior nearly to the intersegmental furrows of the segment. There are one, two, or three of these markings, located on segment xviii, or on xviii and xix, or xviii, xix, and xx. A few specimens have a pair of papillae in xviii instead of the single papilla. 
The penial setae are $3-4 \mathrm{~mm}$. long, 66-74, micra thick at the widest region of the tip, 50-52 micra thick at the narrow region just behind the tip, and 52-56 micra thick at the inner end. The shaft is nearly straight except for a slight bend near the diamond-shaped enlargement at the tip, and is ornamented by short sparsely distributed, toothed ridges.

The spermathecal ampulla is more or less heart shaped, two to three times the length of the duct. An elongate diverticulum is attached to the right and to the left sides of the base of the duct.

The prostates extend through xvii-xxi or xviii-xxii, and are 18-24 $\mathrm{mm}$. long. The duct is $1-2 \mathrm{~mm}$. long. The vasa deferentia of a side come into contact in xii but do not fuse until after they have passed under the prostatic duct and turned inwards toward the nerve cord. The fused duct is enlarged for two or three millimeters before passing into the parietes.

\section{EUTYPHOEUS PLANATUS, new species}

Description of the type-specimen, external characteristics (Cat. No. 19258, U.S.N.M.).-Length, $120 \mathrm{~mm}$. Diameter, 5-8 mm. Color: Deep rich brown. Number of segments, 149 .

The prostomium is prolobous, large.

On segments ii-xii, inclusive, there is a deep secondary furrow posterior to the setae of the segment. On segments $\nabla-x i i$, inclusive, there is a second deep furrow posterior to the setae of the segment. On vi-ix there is a slight tertiary furrow on the posterior third of the segments. On viii-x there is a slight tertiary furrow on the anterior third of the segments. Posterior to the clitellum there are two slight secondary furrows on each segment, one anterior to and one posterior to the setae of the segment.

The first dorsal pore is in $11 / 12$. There are pores in $12 / 13,17 / 18$, and posteriorly.

The setae are eight per segment, they begin on segment ii. Anterior to the clitellum $a b$ is less than $c d$, and $a a$ is greater than $b c$. Posterior to the clitellum $a b$ is less than $c d$ and $b c$ is $2 / 3$ to $3 / 4 a a$, $d d$ is greater than one-half of the circumference.

The clitellum begins just behind the setae of xiii and extends to 17/18. No dorsal pores or intersegmental furrows are present. Setae are present in normal positions with the exception of $a$ and $b$ on each side of xvii.

The male apertures are conspicuous openings in the region $b c$, at the top of tubular porophores projecting from the bottom of the depression in the body wall on xvii.

The female pore is single, anterior to the setae, about halfway between setal lines $a$ and $b$, at the bottom of a slight concavity on the left side of segment xiv. 
The spermathecal pores are in $7 / 8$ in $b c$, close to $b$.

There are two genital markings. The anterior marking is an elongate, oval, lighter colored depression on 13/14, extending from the setae of xiii, to the setae of xiv, and laterally on each side to about half way between $b$ and $c$. The posterior marking is a deep depression in the body wall of xvii, in $b b$. On the floor of this depression in the region $a a$ are four elongate white papillae. External to these papillae and also on the floor of the depression are the columnar male porophores. The body wall around the mouth of the depression lacks the brown pigment and is much wrinkled.

Internal anatomy. - Septa $4 / 5$ and $5 / 6$ are much thickened, especially $5 / 6 ; 6 / 7$ and $7 / 8$ are missing; $8 / 9$ and $9 / 10$ and $10 / 11$ are much thickened and displaced posteriorly together; $11 / 12$ is represented only by the thin connective tissue which forms the wall of the median testic-

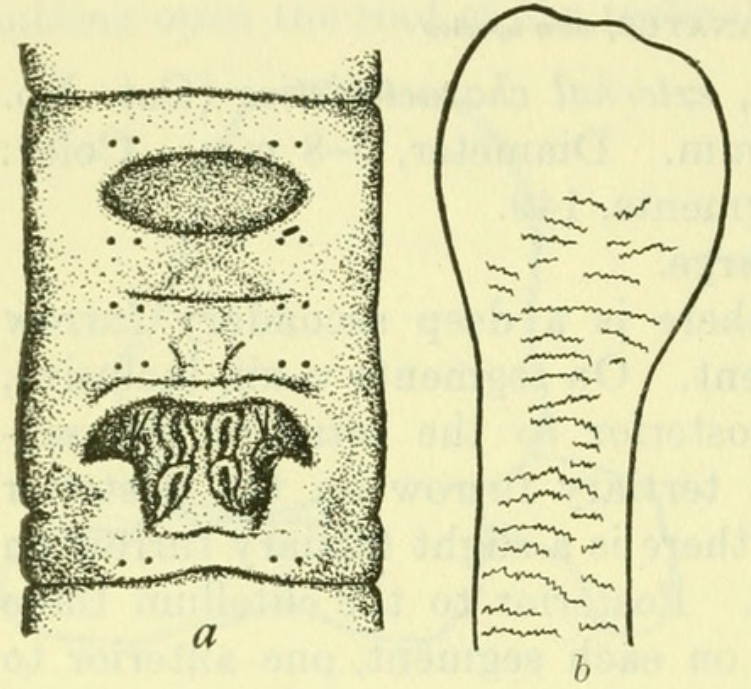

Figure 20.-Eutyphoeus planatus. $a$. Genital AREA. b. TIP OF PENIAL SETA $\times$ ABOUT 412 ular chamber. The remaining septa are thin and attached normally.

The gizzard is subspherical. There are calciferous glands in the wall of the alimentary canal in xii. The intestine begins in $\mathrm{xv}$.

There are large tufted masses of nephridia adherent to the parietes in iii.

Posterior to the gizzard are seven pairs of commissures, two pairs under $8 / 9$, one pair in the median testicular chamber, and one pair in each of segments ix, $x$, xii, and xiii.

The testes and the male funnels are enclosed in a median chamber on the posterior face of 10/11. The seminal vesicles are large, in contact dorsally, and extend from $10 / 11$ to $12 / 13$, pushing $12 / 13$ and $13 / 14$ into contact with $14 / 15$. The tubular prostates extend through segments $\mathrm{xvii}-\mathrm{xx}$. The duct is confined to xvii and is looped several times.

The ovaries and oviduct funnels are in the usual positions in xiii. The spermathecal ampulla is large and flattened out by the gizzard, the duct is short and stout; a club-shaped diverticulum of three seminal chambers is attached to the right and to the left sides of the duct.

Distribution.-Prome, Thayetmyo.

Remarks. - The type-specimen is probably not a complete worm. The posterior opening of the alimentary canal is not a normal anus and the length of the worm is not as great as is usual in similar 
species of this genus. The tail portion of the worm was doubtless amputated some time prior to the time of collecting and the broken end was healed over without producing new segments to replace the lost ones. Shorter fragments of the same species are the only other specimens included in the present collections.

The first dorsal pore is in 11/12. The clitellum begins just posterior to the setae of xii, at $12 / 13$, or just anterior to the setae of xiii.

Setal interval $a a$ varies from one and one-half to two times $b c$.

One specimen has a small oval marking on xiv in $a a$ just behind the setae. Another specimen has a large oval marking on xii in $b b$, just behind the setae.

The prostatic duct is 7 to $8 \mathrm{~mm}$. long.

The penial setae are $3 \mathrm{~mm}$., or less in length, 48-50 micra thick across the tip, 25-28 micra thick at the narrowest point just behind the tip, and about 40 micra thick at the inner end. The tip of the seta is flattened out into a wide spatulalike structure. The ornamentation begins on the flattened portion, extends along the shaft for about $0.3-0.4 \mathrm{~mm}$., and consists of numerous irregular and broken ridges of jagged teeth.

EUTYPHOEUS SIMILIS, new species

Description of the type-specimen, external characteristics (Gates collection).-Length, $177 \mathrm{~mm}$. Diameter, 4-7 mm. Number of segments, 229. Color: Unpigmented, light greyish white, except on the clitellum, which is reddish brown.

The prostomium is prolobous.

On segments iv-xii, inclusive, there is a deep secondary furrow posterior to the setae. On segments vi-xii there is a deep secondary furrow anterior to the setae. On segments xi and xii there is a slight tertiary furrow on the anterior and the posterior thirds of the segment. On segment xiii there are two slight furrows anterior to the setae.

The first dorsal pore is in $11 / 12$. Pores are also present in $12 / 13$, $17 / 18$, and posteriorly.

The setae are eight per segment and begin on ii. Just posterior to the clitellum $a b$ is less than $c d, c d$ is less than $b c$, and $a a$ is larger than $b c, d d$ is greater than one-half of the circumference. More posteriorly $b c$ and $c d$ decrease in size and become nearly equal.

The clitellum begins anterior to the setae of xiii and extends to just behind the setae of xvii. Intersegmental furrows and dorsal pores are lacking.

The male pores are conspicuous transverse slits on xvii. The center of each pore is in line with seta $b$. Two reddish setae project from each pore. 
The female apertures are small diagonal slits on xiv, anterior to the setae and just internal to line $a$, on a whitish oval area.

The spermathecal pores are in line with seta $b$, in $7 / 8$.

The genital markings are paired round papillae on xvi and xvii. The papillae of xvi are nearly twice the size of those on xvii. The anterior pair extend from internal to $a$ to halfway between $b$ and $c$. The posterior pair extend from just internal to $b$ to halfway between $b$ and $c$. At the center of each papilla is thetransverse slit-shaped male aperture.

Internal anatomy. - Septa $4 / 5$ and $5 / 6$ are thickened, $5 / 6$ about twice as much as $4 / 5 ; 8 / 9$ and $9 / 10$ are thickened; $10 / 11$ is slightly thickened; $11 / 12$ is attached normally only to the ventral parietes; $6 / 7$ and $7 / 8$ are absent. Segment xi isreduced to a median testicular

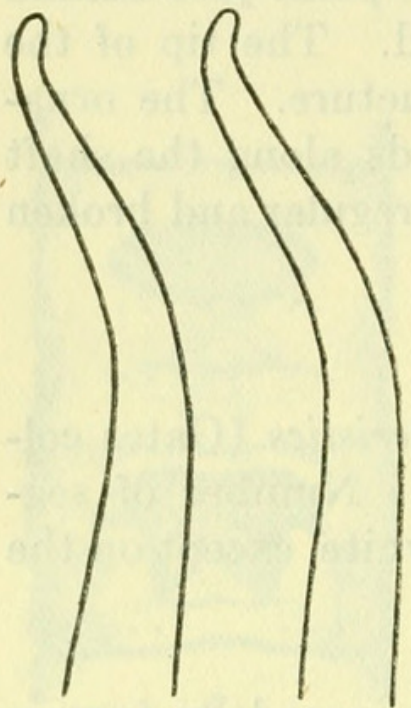

Figure 21.-Eutyphoeus SIMILIS. TIPS OF PENIAL SETAE chamber by the fusion of $11 / 12$ to $10 / 11$ laterally and dorsally.

The gizzard is subspherical. Calciferous glands are embedded in the wall of the alimentary canal in xii. The intestine begins in $\mathrm{xv}$. There is a pair of small caeca at the sides of the intestine in xxviii.

There are tufted masses of nephridia adherent to the parietes in the region of segment iii.

There are three pairs of commissures in the combination gizzard segment, the dorsal blood vessel ending with the anteriormost pair. The last pair of hearts is in xiii.

The testes and the male funnels are inclosed within the median chamber on the posterior face of $10 / 11$. The seminal vesicles are large, in contact with $10 / 11$ anteriorly, and posteriorly pushing $12 / 13$ and $13 / 14$ back into contact with $14 / 15$. The tubular prostates extend through xvii and xviii and are broken into two coiled masses by $17 / 18$. The duct is about $3 \mathrm{~mm}$. long and coiled twice. The vasa deferentia are enlarged as they pass into the parietes just behind the prostatic duct.

The ovaries and oviduct funnels are in the usual positions in segment xiii. The spermathecal ampulla is large and ovoid. The duct is short and practically confined to the body wall. The diverticula are short whitish projections from the right and from the left sides of the duct.

Distribution.-Kyundo, Kawkareik.

Remarks.-Aside from the type-specimen only anterior fragments of this worm are available for study. These vary in diameter from $5-7 \mathrm{~mm}$. The first dorsal pore is $11 / 12$ in all specimens. 
All the fragments have the paired papillae on xvi and xvii. One worm has a larger papilla on the right side of xxi, pushing $20 / 21$ and $21 / 22$ anteriorly and posteriorly, and extending from internal to $a$ nearly to $c$. Another worm has a similar area in the same position on each side of xxi.

The supra-intestinal glands are 10 pairs in 5 successive segments, $85-95 \mathrm{~mm}$. from the anterior end.

The penial setae are $1.8-2.4 \mathrm{~mm}$. long, 50-55 micra thick at the widest region near the base. The shaft is straight except for two slight bends near the free end. The ornamentation consists of irregularly placed, finely jagged ridges which are shorter and sparsely distributed near the tip, longer and closer together toward the base.

The worm just described is very similar in general external appearance as well as internal structure to E. peguanus. Some two score

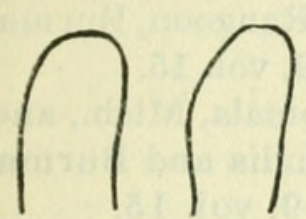

FigurE 22.-EUTYPHOEUS SIMILIS SPERMATHECAL DIVERTICULA $\times$ ABOUT 14 specimens of the latter species, from the type-locality, Rangoon, have been available for comparison with the Kyundo form. The differences between the two forms may be summarized as follows:

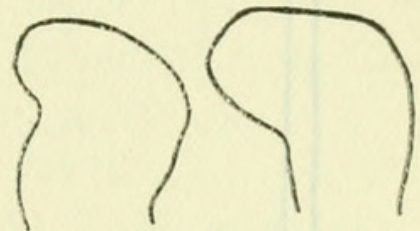

Figure 23.-E U T Y P HOE US PEGUANUS. SPERMATHECAL DIVERTICULA $\times$ ABOUT 14

\section{E. similis}

Male pores........... In $b c$ close to $b$. On the posterier third of longitudinally placed oval papillae.

Spermathecal pores In $b c$, to $c$

In line with $b$. On the center of $\mathrm{round}$ papillae.

In $b$.

Clitellar genital markings_.... Paired, on xvii only _._.....

Extra clitellar markings

Male funnels

Prostatic duct

Penial setae:

Length

Basal thickness

Curvature.

Spermathecal diverticulum.
Paired, on xix

In $\mathrm{x}$ and $\mathrm{xi}$ (not hitherto recorded from $x$ in this species).

7-8 mm. long.

$1.3-1.8 \mathrm{~mm}$

35-50 micra

One

Usually bent
Paired, on xvi and $\mathrm{xvii}$.

Paired, on xxi.

In xi only.

2-3 mm. long.

\section{8-2.4 mm.}

50-55 micra.

Two.

Usually not bent, smaller.

So far as the majority of the characteristics listed above are concerned, the two forms are sharply delimited and do not grade into each other. The curvature of the penial setae and the form of the spermathecal diverticulum do, however, vary somewhat in both forms.

The majority of the normal penial setae of $E$. peguanus are curved as illustrated, although several setae were found with a shaft 
curvature resembling that figured for the other species. Similarly, diverticula were found in several specimens of $E$. peguanus that are not bent and similar to the diverticula of the other species. But the diverticula from the large majority of worms examined conform to the types figured. Both characters, that is, structure of the tip of penial setae and shape of the diverticula are similarly variable in well-defined species.

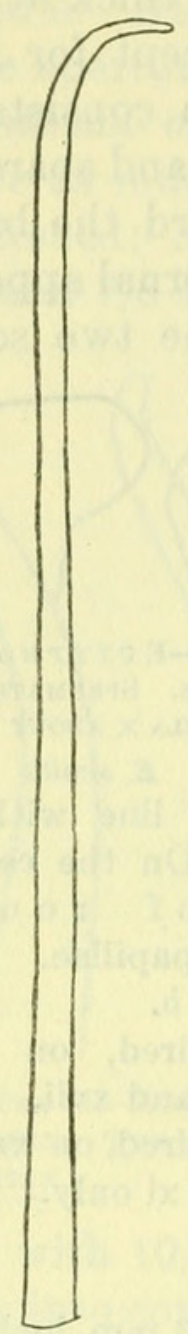

Figure 24.-EUTYPHOEUS PEgUANUS. PENIAL SETA, DRAWN FROM A MICROPHOTOGRAPH

\section{BIBLIOGRAPHY}

BEDDARD, F. E.

1883-Note on some earthworms from India. Ann. Mag. Nat. Hist., ser. 5, vol. 12.

1893-On some new species of earthworms from various parts of the world. Proc. Zool. Soc., 1892.

Gates, G. E.

$1925 a$-Some new earthworms from Rangoon, Burma. Ann. Mag. Nat. Hist., ser. 9, vol. 15.

$1925 b$ - Some notes on Pheretima anomala, Mich., and a related species new to India and Burma. Ann. Mag. Nat. Hist., ser. 9, vol. 15.

1925 - -Some new earthworms from Rangoon, Burma. II. Ann. Mag. Nat. Hist., ser. 9, vol. 16.

$1925 d$ - Note on a new species of Drawida from Rangoon, Burma. Ann. Mag. Nat. Hist., ser. 9, vol. 16 .

$1926 a$-Note on a new species of Pheretima fro $\mathrm{m}$ Rangoon. Ann. Mag. Nat. Hist., ser. 9, vol. 17.

$1926 b$-Notes on the Rangoon earthworms. The

- peregrine species. Ann. Mag. Nat. Hist. ser. 9, vol. 17 .

$1926 c$ - Notes on the seasonal occurrence of Rangoon earthworms. Journ. Bombay Nat. Hist. Soc., vol. 21.

$1926 d$ - The earthworms of Rangoon. Journ. Burma Research Soc., vol. 15.

$1926 e$ - Notes on earthworms from various places in the Province of Burma, with descriptions of two new species. Rec. Ind. Mus., vol. 28.

$1927 a$-Note on Perichaeta campanulata Rosa and Pheretima houlleti (E. Perr.). Ann. Civ. Mus. Genova., vol. 52. $1927 b$ - Note on a new species of Notoscolex, with a list of the earthworms,

Michaelsen, W.

$$
\text { of Burma. Ann. Mag. Nat. Hist., ser. 9, vol.19. }
$$

1907-Neue Oligochäten von Vorderindien, Ceylon, Birma und den Andaman-Inseln. Mitt. Mus. Hamburg, vol. 24.

1908-The Oligochaeta of India, Nepal, Ceylon, Burma, and the Andaman Islands. Mem. Ind. Mus., vol. 1.

RosA, D.

1888-Viaggio di Leonardo Fea in Birmania e Regioni vicini. V. Perichetidi. Ann. Civ. Mus. Genova, ser. 2, vol. 6. 
1890a-Viaggio di Leonardo Fea in Birmania e Regioni vicini. XXV. Moniligastridi, Geoscolecidi, ed Eudrilidi. Ann. Civ. Mus. Genova, ser. 2, vol. 9.

$1890 b$ - Viaggio di Leonardo Fea in Birmania e Regioni vicini. XXVI. Perichetidi. Ann. Civ. Mus. Genova, ser. 2, vol. 9.

\section{Stephenson, J.}

1912-Contributions to the fauna of Yunnan. VIII. Earthworms. Rec. Ind. Mus., vol. 7 .

1916-On a collection of Oligochaeta belonging to the Indian Musuem. Rec. Ind. Mus., vol. 12.

1918-Aquatic Oligochaeta of the Inle Lake. Rec. Ind. Mus., vol. 14. 1923-Oligochaeta. Fauna British India Series. London.

1924-On some Indian Oligochaeta, with a description of two new genera of Ocnerodrilinae. Rec. Ind. Mus., vol. 26. 


\section{$2 \mathrm{BHL}$ Biodiversity Heritage Library}

Gates, G. E. 1929. "A summary of the earthworm fauna of Burma with descriptions of fourteen new species." Proceedings of the United States National Museum 75(2781), 1-41. https://doi.org/10.5479/si.00963801.75-2781.1.

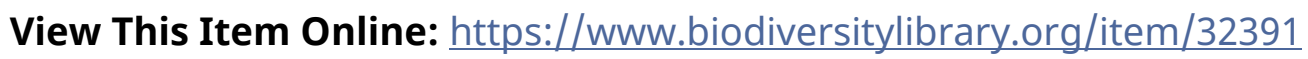

DOI: https://doi.org/10.5479/si.00963801.75-2781.1

Permalink: https://www.biodiversitylibrary.org/partpdf/7795

\section{Holding Institution}

Smithsonian Libraries

\section{Sponsored by}

Smithsonian

\section{Copyright \& Reuse}

Copyright Status: NOT_IN_COPYRIGHT

Rights: https://www.biodiversitylibrary.org/permissions/

This document was created from content at the Biodiversity Heritage Library, the world's largest open access digital library for biodiversity literature and archives. Visit BHL at https://www.biodiversitylibrary.org. 